\title{
Potential Applications of Milk Fractions and Valorization of Dairy By-Products: A Review of the State-of-the-Art Available Data, Outlining the Innovation Potential from a Bigger Data Standpoint
}

\author{
Serge Rebouillat ${ }^{*}$, Salvadora Ortega-Requena ${ }^{2}$ \\ ${ }^{1}$ Currently with DuPont Int. Op. European Headquarter, Geneva, Switzerland \\ ${ }^{2}$ Chemical Engineering Department, University of Murcia, Murcia, Spain \\ Email: sergereb@yahoo.com
}

Received 4 June 2015; accepted 7 July 2015; published 13 July 2015

Copyright (C) 2015 by authors and Scientific Research Publishing Inc. This work is licensed under the Creative Commons Attribution International License (CC BY). http://creativecommons.org/licenses/by/4.0/

\section{(c) (i) Open Access}

\section{Abstract}

The unique composition of milk makes this basic foodstuff into an exceptional raw material for the production of new ingredients with desired properties and diverse applications in the food industry. The fractionation of milk is the key in the development of those ingredients and products; hence continuous research and development on this field, especially various levels of fractionation and separation by filtration, have been carried out. This review focuses on the production of milk fractions as well as their particular properties, applications and processes that increase their exploitation. Whey proteins and caseins from the protein fraction are excellent emulsifiers and protein supplements. Besides, they can be chemically or enzymatically modified to obtain bioactive peptides with numerous functional and nutritional properties. In this context, valorization techniques of cheese-whey proteins, by-product of dairy industry that constitutes both economic and environmental problems, are being developed. Phospholipids from the milk fat fraction are powerful emulsifiers and also have exclusive nutraceutical properties. In addition, enzyme modification of milk phospholipids makes it possible to tailor emulsifiers with particular properties. However, several aspects remain to be overcome; those refer to a deeper understanding of the healthy, functional and nutritional properties of these new ingredients that might be barriers for its use and acceptability. Additionally, in this review, alternative applications of milk constituents in the non-food area such as in the manufacture of plastic materials and textile fibers are also introduced. The unmet needs, the cross-fertilization in between various protein domains,

\footnotetext{
"Corresponding author.
} 
the carbon footprint requirements, the environmental necessities, the health and wellness new demand, etc., are dominant factors in the search for innovation approaches; these factors are also outlining the further innovation potential deriving from those "apparent" constrains obliging science and technology to take them into account.

\title{
Keywords
}

\author{
Milk Product, Milk Fractionation, Casein, Phospholipid, Whey Protein, Non-Food Application, \\ Valorization, Enzyme Modification, Bioactive Peptides, Bigger Data, Innovation: Closed, Open, \\ Collaborative, Disruptive, Inclusive, Nested
}

\section{Introduction and Preliminaries}

Rebouillat et al. [1]-[6] set the stage for the innovation key citations listing and their own interpretations of some of them, it is worth repeating those, with some editing of the main author, as introductory points to reflect on; adding provocative new illustrations (Illustration 1 and Illustration 2) that further focus on the challenges and opportunities ahead of innovation reviewers and experts, especially here in the biotechnology and green contexts.

As already mentioned by Rebouillat et al. [1]-[6], "Innovation, a subject of massive interest:

- is multiple and subject to overlapping descriptors: Closed, Open, Collaborative, Disruptive, Inclusive, Nested... and soon Reverse.

- "Innovation is not the idea but what you do with it."

- "is the future of innovation in essence predictable?"

- " "is a stronger-than-logic Creative Path based on Curiosity and Confidence."

- necessitates strong implementation discipline and clarity and has to be competitively unpredictable.

- does include the bricolage model and approach associated with trial and error, learning on the job; the question of serendipity and the role chance.

- requires to realize that "all the best people do not work for the same company".

- is probably best handled by small autonomous teams, as small as 5 members, probably not bigger than 80 , possibly 15 on average in large corporations.

- cannot be "cloned"; Innovation cultures are hardly transferable.

- "R\&D spending or R\&D intensity as indicators of innovation may result in either overestimates or underestimates".

- most results suggest that "raw patent data is an imperfect proxy for innovation".

- patent exploration constitutes a wealth of innovation potential, as simple as image analysis to combinatorial therefrom.

- is moving towards fundamental co-creation with intense purposeful networking.

- and with the advent of Big Data: "Word is worth a million images".

- ... not without a business model."

Illustration 1 and Illustration 2 provide self-explanatory representations of the skills and dimensions of the Innovation at large.

And then can Innovation be measured? When and How?

Most of the above comments on innovation are introduced in the five chapters on Innovation, hosted by IJIAS; some are illustrated here such as via the bigger data contribution to interlinked neighboring matters in a multiplying synergism approach. Previous Rebouillat et al.'s reviews [1]-[6] are further basis outlining innovation and the realities around those recurring questions; can Innovation be measured? When and How?

The core subject matter of the current review enjoys a good level of publication and citations that is illustrated on Figure 1.

Among those selected references used for Figure 1, a repartition chart (Figure 2) provides a relative importance of the matters of interest in the current review. Innovation represents a total of $10 \%$ while byproducts related aspects amount to $25 \%$, the non-food applications $3 \%$ and the green chemistry per say $1 \%$. The milk fractions-food applications are largely dominant. 


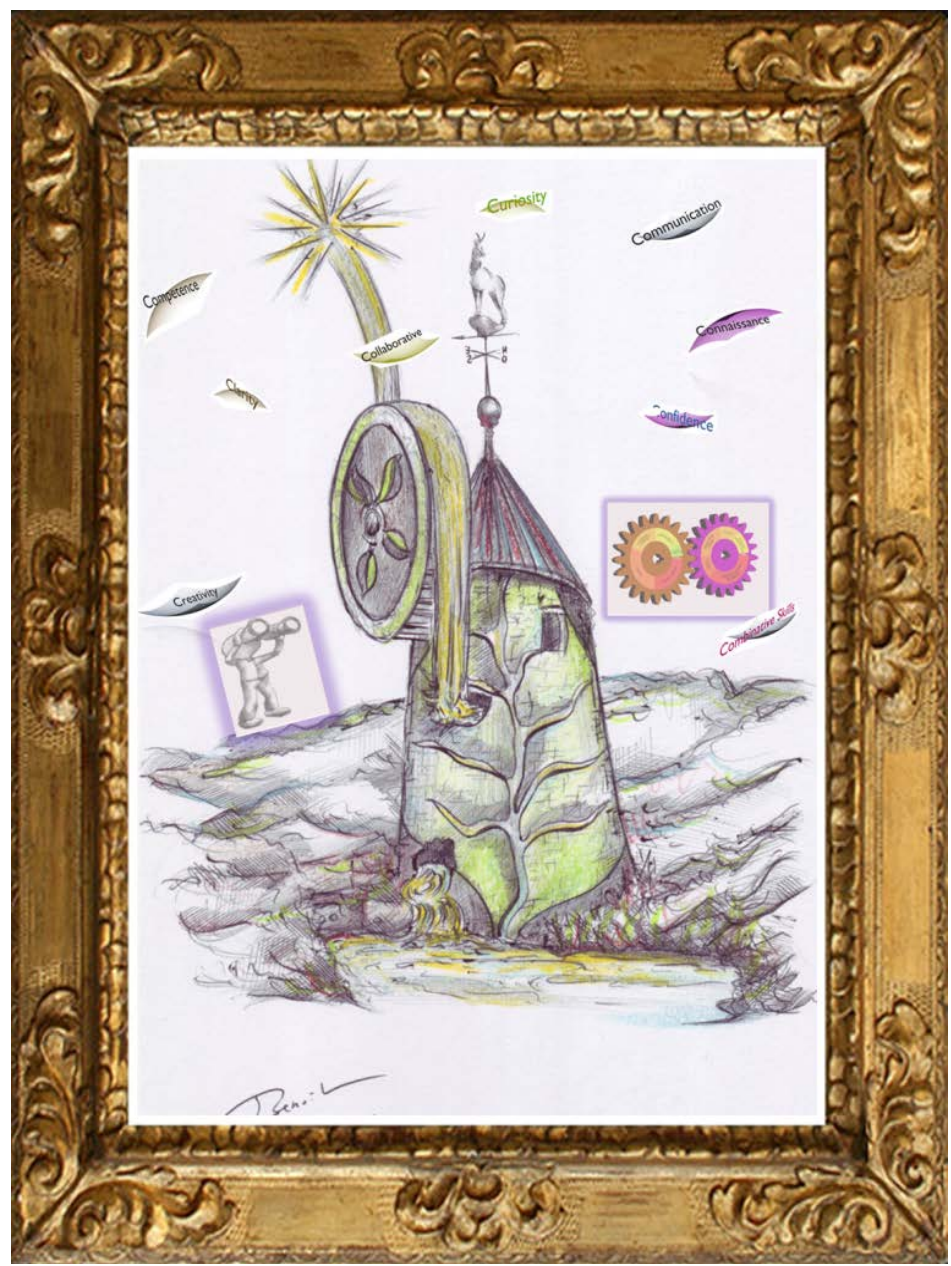

Illustration 1. The "SWHPM", interpreted by artist BS, is a disruptive prophetic concept of the author making use of Sun, Wind, Hydraulic, Photosynthesis, Gravitational, Geographical Gradients to power a milllike generator of various energy streams.

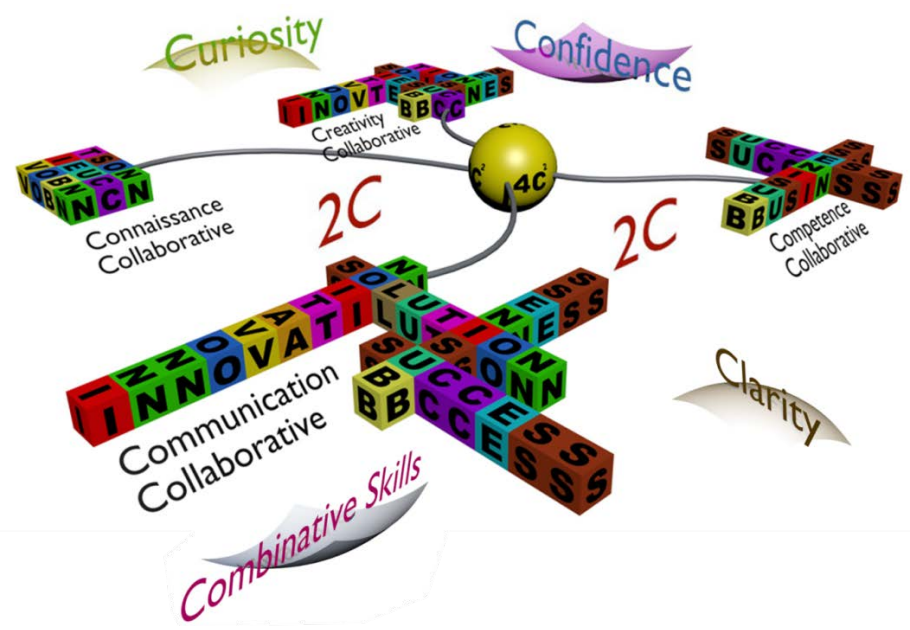

Illustration 2. The Multiplying Dimensions of the Innovator, at large technical, science and business, now amount to 4C2 2Cx2C@ as per Rebouillat et al. [1]-[5]. 


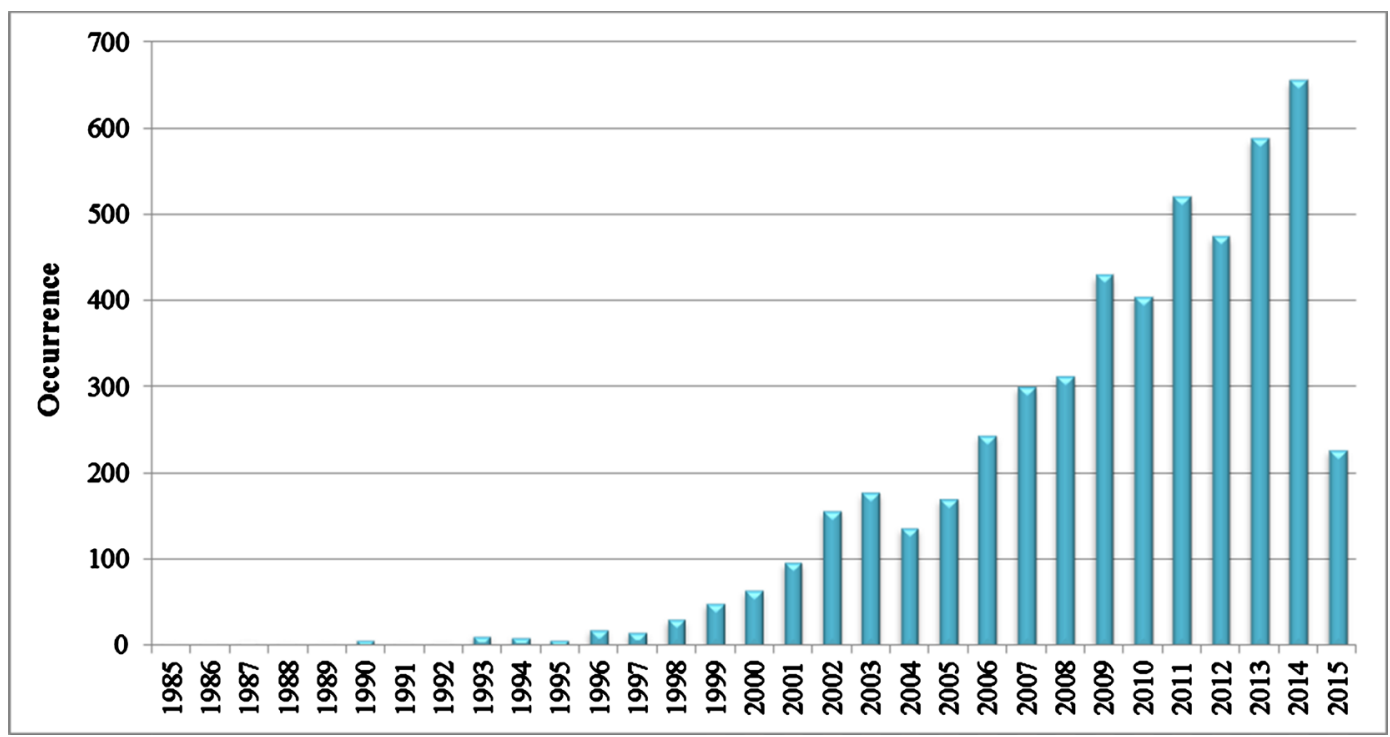

Figure 1. Citations per year (Occurrence) in the field of interest using about 100 listed references used in the current review.

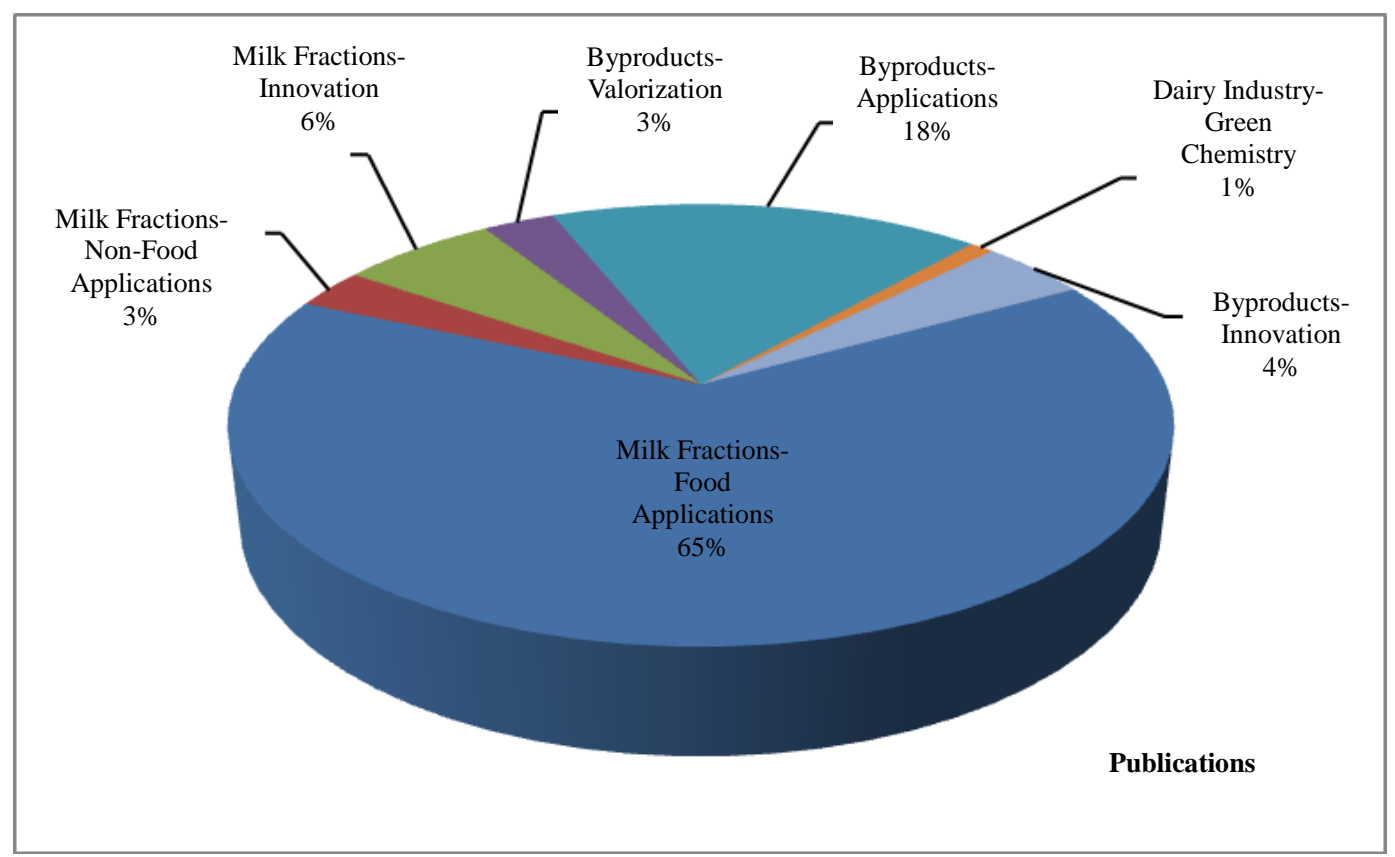

Figure 2. The relative importance of the matters of interest in the current review using about 100 listed references used in the current review.

The patent activity, among other IP activities, is a key criterion to integrate and appreciate key practices in the field; it also helps to judge the level of disruptive innovation occurring in the field.

Figure 3 shows the progression of patents applications and their granted proportion in various regions; "WO" for the PCT (Paris Convention Treaty) coverage, generally over several PCT member countries in the world, "EP" for the European ones, "CA" for the Canadian part and "Other" for the remaining coverage.

A striking observation is the rather synchronized occurrence of patents versus scientific publications; the types of progression are rather mirrored; taking into account the time allowance for publications. Typically the publication time is a fixed 12 or 18 month period for patents and generally a 6 to 12 month span for regular papers;9 month average for chemistry publications [7]. 


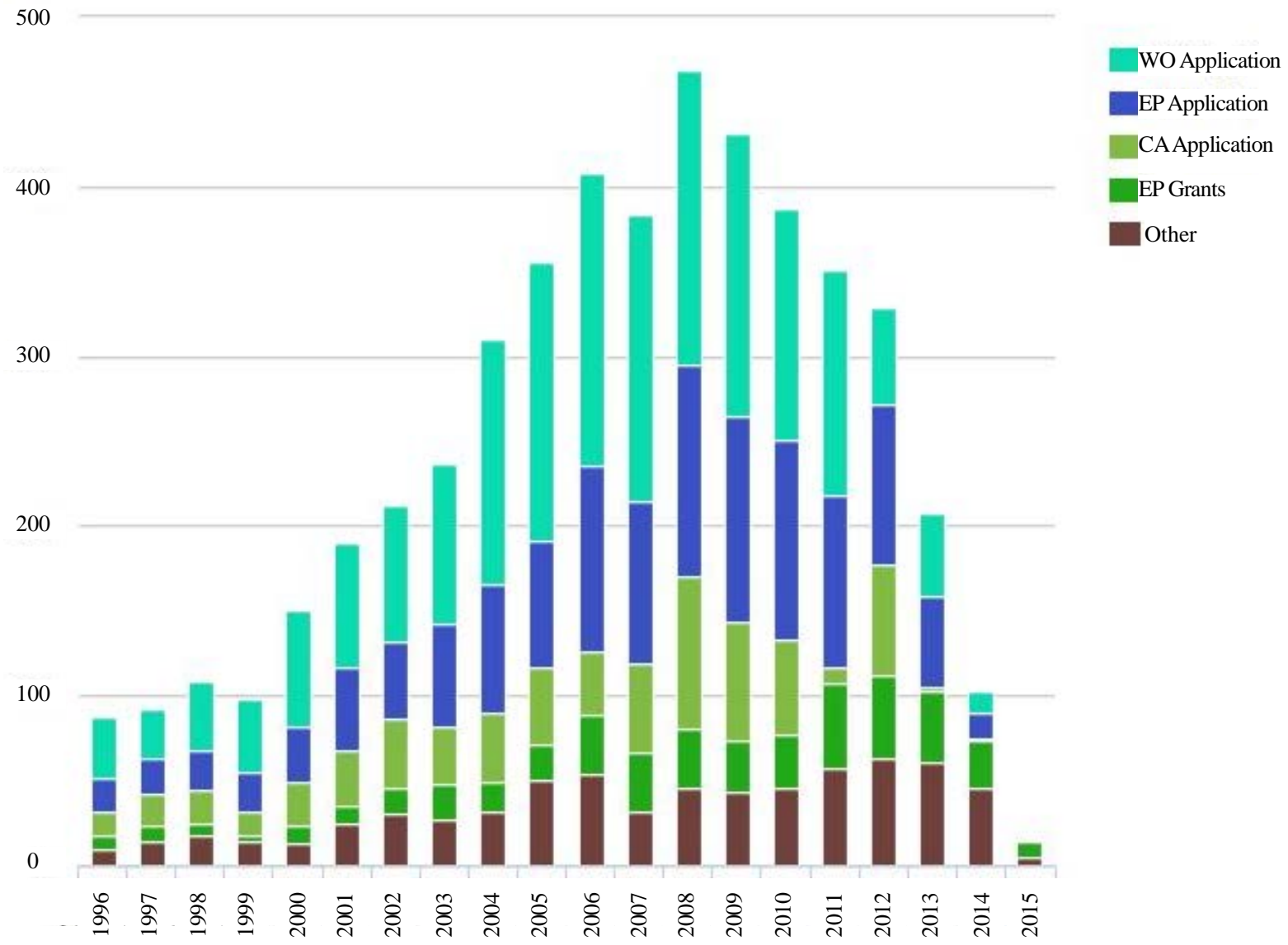

Figure 3. The patent repartition per region per year in the field of interest using a sample of 5000 patents (from a standard state of the art semantic analysis using title, keywords, introduction and conclusion of the present review-selected relevance level $80 \%)$.

A much larger picture is worth the view.

The representation of liaisons between the most appearing keywords/concepts (nodes) in selected patent portions (such as claims, specifications, abstract or title) helps understand the existing technology connections among various protein sources.

Figure 4 provides, for educational value, an example of such a representation based on 20,000 patents and associated scientific papers, non-patent literature (NPL). On that figure a tetrahedral figure, delineated with the coarser lines representing the largest numbers of connections, appears among the three selected sources of protein and the food ingredients.

This tends to reflect that the paradigm or orthodoxy that assumes a lack of relationship in practice between food and vegetable proteins would not be supported by technology and scientific similarities/concordances/cooccurrences.

Then this review also has the goal of closing the gap among various sources of protein and possibly of outlining the synergism factors.

Milk and milk products such as butter, cheese and fermented products have been consumed by humankind for millennia. The early history of milk use has been dated back to $7000 \mathrm{BC}$, following the animals domestication, when the ancestors stopped being nomadic. Since then, dairy products were present in different civilizations. The Egyptian papyrus reflected the obtaining of milk. Greek mythology praises the value of milk and curds. Hippocrates described its medicinal effects. The Romans consumed cheese and milk for its believed rejuvenating properties. Milk-derived products continued evolving through the centuries. The turning point for the development of the dairy industry occurred in 1863, when Louis Pasteur developed a method of killing harmful bacteria known as pasteurization. 


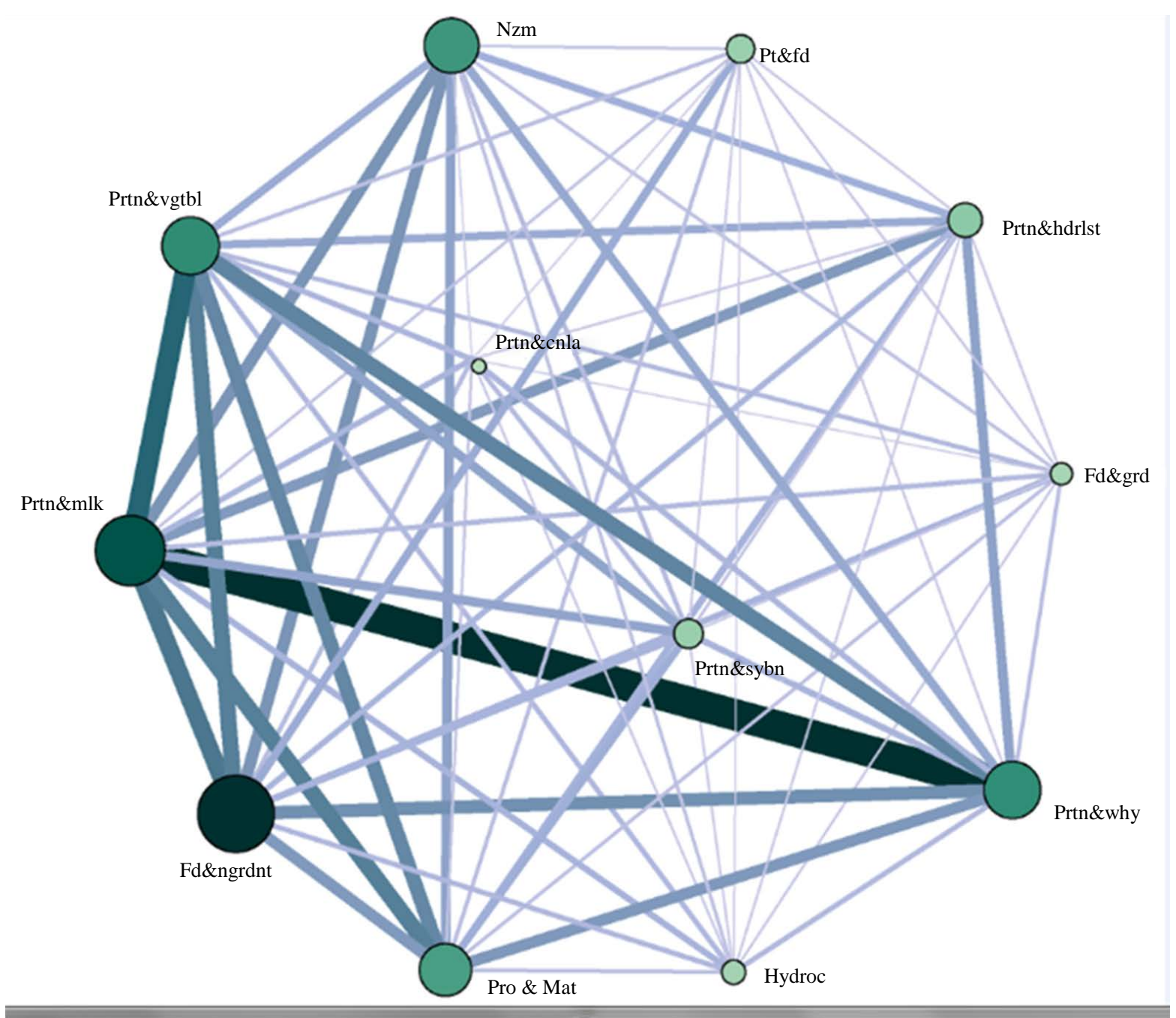

Figure 4. The protein neural network (co-occurrence chart) based on 20000 patents and NPL of the selected field. (Prtn\&x), ( $\mathrm{x}=$ mlk, why, vgtbl respectively milk, whey, vegetable), (food ingredients = Fd\&ngrdnt).

As an outstanding source of essential nutrients, milk can be defined as "the most nearly perfect food". Its unique composition of nutritional components (Table 1) makes it perfect not only to be consumed directly as a beverage or transformed into a range of traditional dairy foods, but to exploit it as a rich source of ingredients for food preparations.

The fractionation of milk to obtain products with different composition and properties opens up a wide range of applications for milk fractions as food ingredients. Additionally, milk components can be processed in various ways to create numerous ingredients with diverse functional and nutritional characteristics. Growing concerns for health and environment characterize today's society, which increases the acceptability of food ingredients manufactured from milk, recognized by the consumer as "natural".

Of the different fractions, protein is considered to be the most valuable with an expanding demand for dairy proteins and its derivatives. Constituents of the fat fraction are also attracting attention as potential food ingredients. This report highlights the great potential of value-added products manufactured from those two milk fractions to be used mainly as food ingredients and as nutritional products.

\section{Fractionation of Milk}

Milk components differ in size, structure and physical properties and can be isolated by different processing techniques. These processes generally involve the use of filtration methods based on molecular weight (Figure 5). 
Table 1. Composition of milk [8] [9].

\begin{tabular}{|c|c|c|}
\hline Nutrient & Component & $\%$ \\
\hline Water & -- & 87.4 \\
\hline Caseins & $\begin{array}{l}\alpha_{\mathrm{s} 1} \text {-casein } \\
\alpha_{\mathrm{s} 2} \text {-casein } \\
\beta \text {-casein } \\
\kappa \text {-casein } \\
\gamma \text {-casein }\end{array}$ & $\begin{array}{c}1.2 \\
0.3 \\
1.0 \\
0.35 \\
0.12\end{array}$ \\
\hline Whey proteins & $\begin{array}{l}\alpha \text {-lactalbumin } \\
\beta \text {-lactoglobulin } \\
\text { Serum albumin } \\
\text { Immunoglobulins } \\
\text { Proteose-peptone fraction }\end{array}$ & $\begin{array}{c}0.12 \\
0.32 \\
0.04 \\
0.08 \\
0.1\end{array}$ \\
\hline Fat & $\begin{array}{l}\text { Triacylglycerols } \\
\text { Mono- and Diacylglycerols } \\
\text { Phospholipids } \\
\text { Sterols } \\
\text { Free fatty acids }\end{array}$ & $\begin{array}{l}3.54 \\
0.09 \\
0.04 \\
0.02 \\
0.01\end{array}$ \\
\hline Lactose & -- & 4.8 \\
\hline Ash & -- & 0.7 \\
\hline
\end{tabular}

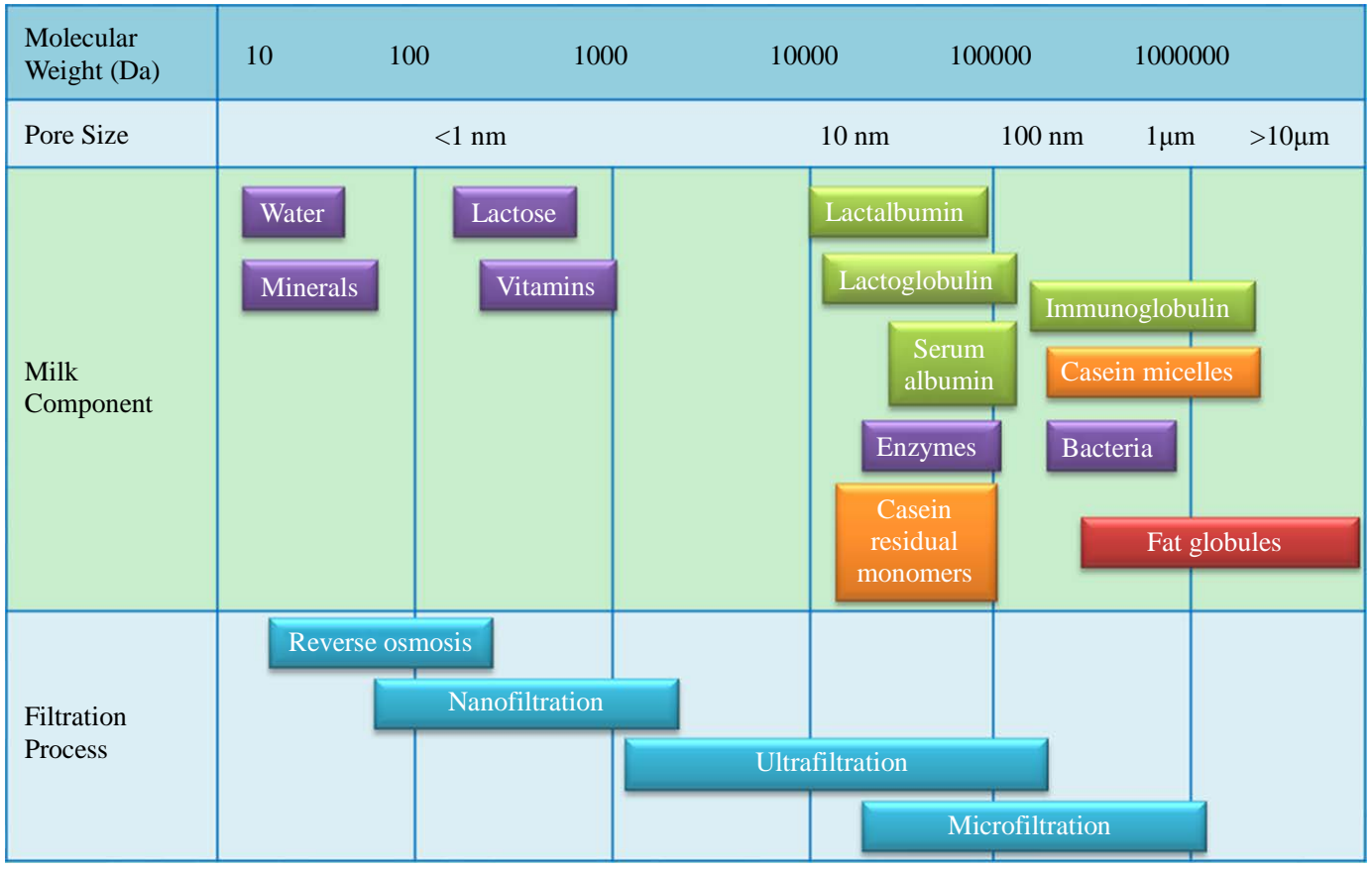

Figure 5. Relative milk component sizes in comparison with membrane pore size ranges [10].

Membrane separation technology is being applied both in traditional dairy processing and for new and innovative applications, to produce value-added dairy products.

Ultrafiltration (UF) was initially used in the dairy industry to pre-concentrate milk before cheese making. It has also been successfully used to recover proteins from whey and concentrate milk proteins from smaller compounds such as lactose, vitamins and minerals. Ultrafiltration of skim milk produces milk protein concentrate (MPC), while ultrafiltration of cheese whey produces whey protein concentrate (WPC) [11]. It is estimated that more than $90 \%$ of whey protein concentrates (WPCs) originates from separating the coagulum from milk, cream, or skim milk in cheese making. Less than $10 \%$ is obtained from casein production, from the curd formation by direct acidification of milk. Valuable whey components can be concentrated or isolated by a number of 
processes. Besides membrane technology, such processes include electrodialysis, ion exchange and crystallization.

Microfiltration (MF) emerged as an industrial separation technology in the dairy industry for bacteria removal, defatting of whey and micellar casein enrichment for cheese making [12]. Nowadays, it is been investigated for its capability to directly isolate caseins and whey proteins from milk [13]-[15]. Another emerging application is the fractionation of milk fat globules with no disruption of the globular membrane [16] [17]. A wide variety of microfiltration-membrane materials, geometric designs, system configurations and operating approaches are available. Two major types of membranes exist: polymeric and ceramic. Their differences lie in cost, membrane life, flux, efficiency, purity of the fractions, cleaning and energy consumption [18].

Fouling is considered the limiting factor in milk filtration, which has led to the development of different strategies to minimize this problem, e.g., uniform transmembrane pressure (UTP), back pulsing, air slugs, rotating or vibrating modules and ion-exchange membranes [12] [19]. Solutions based on the porosity gradient of the membrane support (such as Membralox GP ${ }^{\circledR}$, Pall Corporation) or a variable thickness active membrane layer (such as Isoflux ${ }^{\circledR}$, Tami Industries) (Figure 6), have also been developed [11] [20].

In addition to these membrane processes, supercritical carbon dioxide has been shown to effectively fractionate whey protein fraction to obtain enriched fractions of $\alpha$-lactalbumin and $\beta$-lactoglobulin, as well as to isolate casein glycomacropeptide (an amino acid fragment of $\kappa$-casein) [21] [22].

One of the indicators of the great potential of the fractionation of milk is the number of patents that have been published over the last decade regarding the purification and concentration of its different ingredients. Some examples are: protein fractionation of skim milk by means of microfiltration [23], purification of $\beta$-casein using cross-flow polymeric microfiltration membranes [24], fractionation of $\alpha_{\mathrm{s}}$-casein, $\kappa$-casein and $\beta$-casein [25], concentration of milk proteins using negatively-charged ultrafiltration membranes [26] and manufacturing of compositions richly containing phospholipids and sphingolipids using a supercritical extraction technology [27].

\section{Milk Proteins}

Milk proteins consist of two major groups of proteins called caseins and whey proteins. Of the approximately $3.6 \%$ protein in milk, roughly $80 \%$ is casein and $20 \%$ is whey protein [8].

\subsection{Milk Proteins as Food Ingredients}

Dairy proteins are isolated from skim milk using membrane filtration and obtaining milk protein concentrates (MPCs). MPCs have concentrations ranging from $40 \%$ to $80 \%$, with higher concentrations (>90\%), they are referred to as milk protein isolates (MPIs) (Figure 7). Those milk fractions are rich in bound calcium and contain both whey protein and casein in the same ratio as milk, having good heat stability and clean flavor profile.

The excellent surface-active and colloid-stabilizing characteristics of milk proteins make them highly valued food ingredients, both in soluble and dispersed form [28]. Some of their main functional characteristics are solubility, water binding, gelling, foaming, emulsification and heat stability. Their hydrophilic and hydrophobic
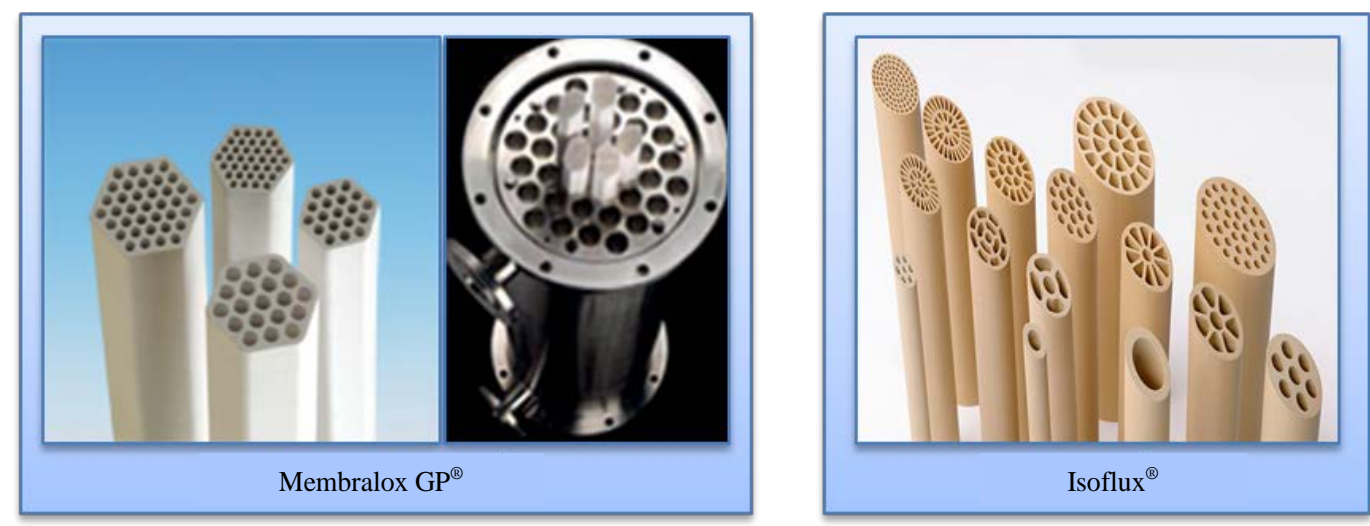

Figure 6. Membralox GP ${ }^{\circledR}$ membrane cross section and membrane module (left). Isoflux ${ }^{\circledR}$ membrane cross section (right) from advertisement brochures. 


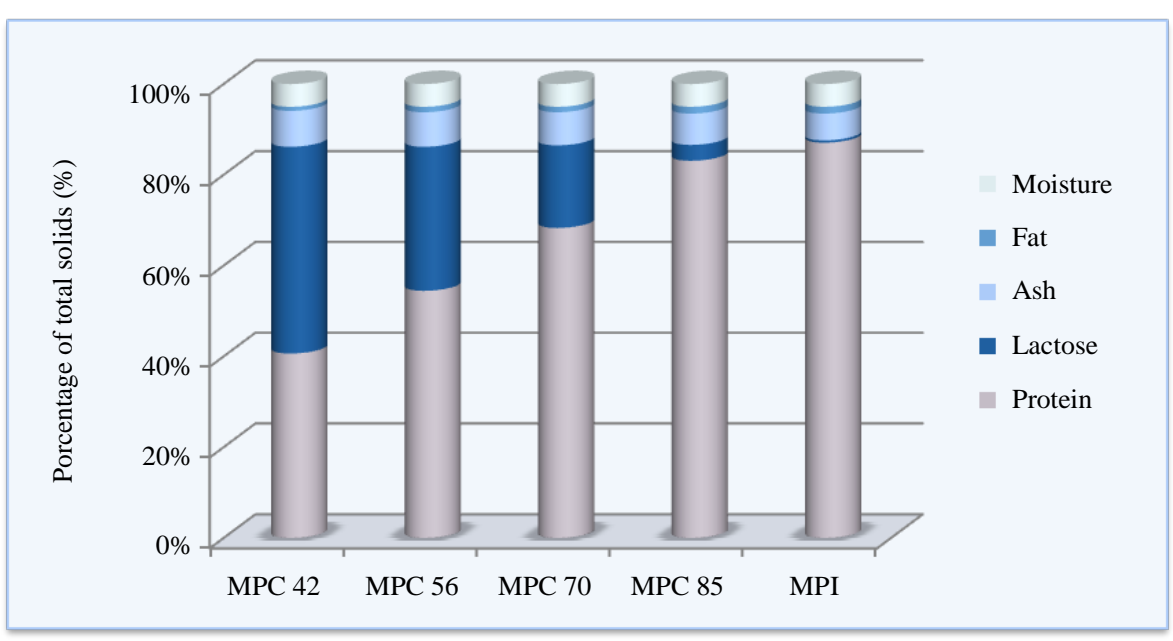

Figure 7. General composition of MPCs.

polar nature makes them desirable emulsifiers used as fat replacers and to improve texture and increase shelf-life in diverse products such as breads, meats and frozen desserts. Thanks to their foaming properties, milk proteins can also be used in whipped products, function that has traditionally relied on eggs. MPCs are currently used as ingredients for manufacturing products including: cheese and yogurt, ice cream, dietetic formulations, cereal and energy bars, infant formulae, desserts, baked goods, toppings, low-fat spreads, sports beverages/foods and geriatric nutritional products.

Caseins and whey proteins have different molecular structures; in contrast to the disordered flexible structure of caseins, whey proteins have a compact globular structure. For that reason, the protein adsorbed layer at the surface of the dispersed droplets for each of them has a specific structure, and consequently the mechanical properties of the stabilized emulsion are different [29] [30]. The relationship between the properties of milk protein adsorbed layers and stability of corresponding emulsion systems for pure milk proteins, including interactions between them and with surfactants, has been extensively studied [31].

\subsection{Groups of Milk Proteins and Their Applications}

\subsubsection{Caseins}

The caseins in milk form complexes called micelles that are dispersed in the water phase of milk. There are diverse models to describe the casein-micelle structure [32]. In one of the most commonly accepted models, the casein micelles consist of spherical subunits or submicelles of the different caseins $\left(\alpha_{\mathrm{s} 1}, \alpha_{\mathrm{s} 2}, \beta\right.$ and $\gamma$ ) held together by calcium phosphate bridges and hydrophobic interactions between proteins on the inside, surrounded by a layer of $\kappa$-casein which helps to stabilize the micelle in solution. There are two main types of submicelles: one consisting of $\alpha_{\mathrm{s}}$ - and $\beta$-caseins, that constitutes the hydrophobic center of the submicelle, and another type consisting of $\alpha_{\mathrm{s}}$ - and $\kappa$-caseins, which is distributed outside of the micelle with the hydrophilic part (the sugar residues of $\kappa$-caseins) forming an outer "hairy layer" (Figure 8) [32].

Being phosphoproteins, each of the caseins has different degree of phosphorylation. While $\alpha_{\mathrm{s}}$-caseins and $\beta$-caseins are highly concentrated in phosphoseryl residues, $\kappa$-casein contains only one or two residue, besides of being glycosylated. Caseins, especially $\beta$-casein, have a large amount of proline residues, which disrupt the formation of $\alpha$-helical and $\beta$-sheet [33]. These proteins are stable at high temperatures but unstable at $\mathrm{pH}$ below 5.0, for that reason they are usually prepared by isoelectric precipitation at $\mathrm{pH}$ 4.6. Coagulation through the action of rennet enzymes and isolation by membrane filtration are other processes to obtain caseins from skim milk.

Owing to the importance of casein micelles for many of the physico-chemical properties of milk and dairy products, their structure (Figure 9), properties and the effects of their composition and processing conditions have been extensively studied [35].

The most important applications of caseins in fabricated foods are cheese analogues, synthetic whipping creams, cream liqueurs, fabricated meats, some cereal products, various dietetic foods and as an emulsifier in coffee whiteners [36]. The amphipathic structure and the lack of stable secondary and tertiary structures of caseins 
Calcium phosphate $\mathrm{Ca}_{9}\left(\mathrm{PO}_{4}\right)_{6}$

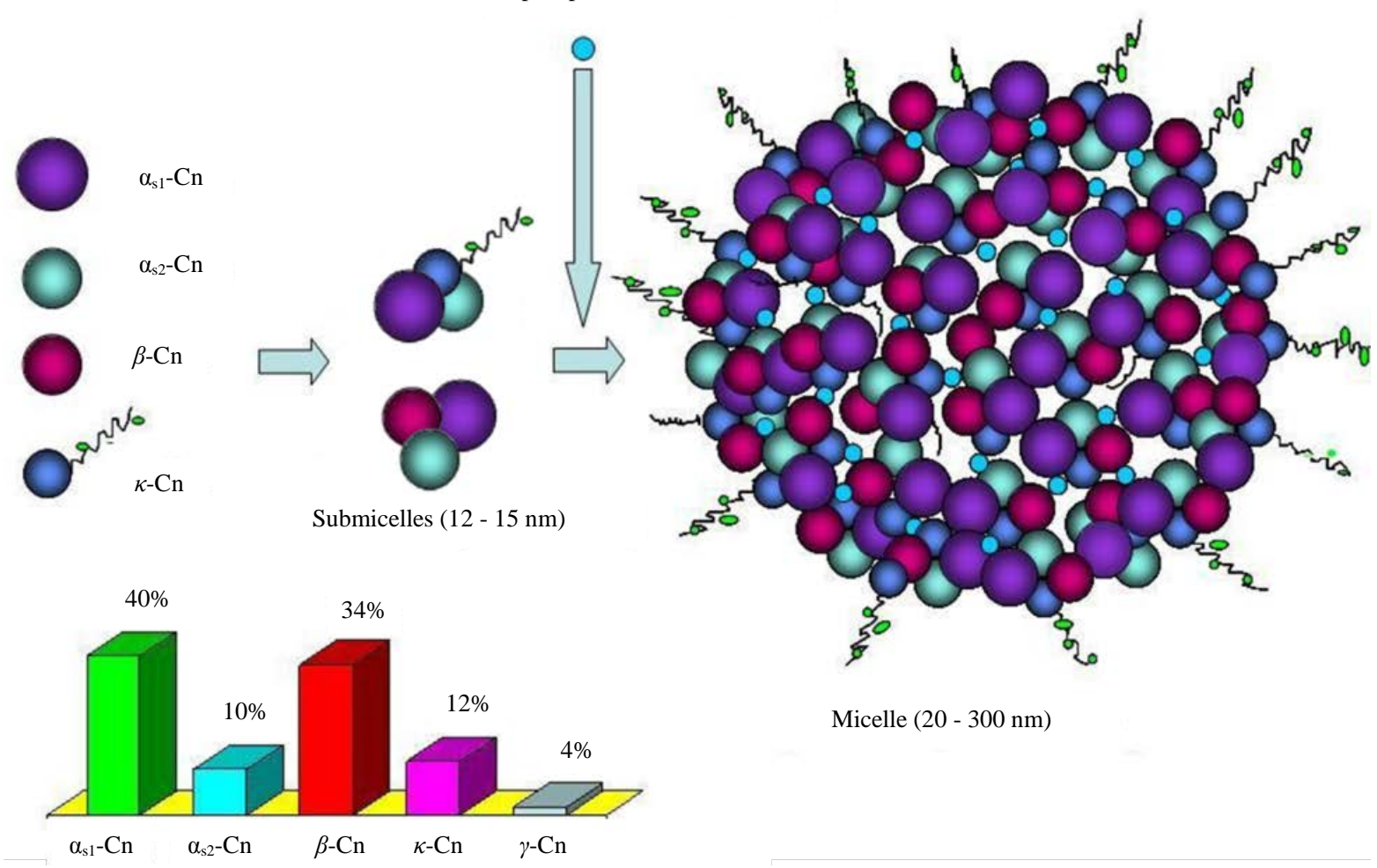

Figure 8. Schematic representation of casein submicelles and casein micelle composed of submicelles held together by calcium phosphate. A bar chart with the amount of the different caseins that comprise the casein fraction is showed (Cn stands for Casein).
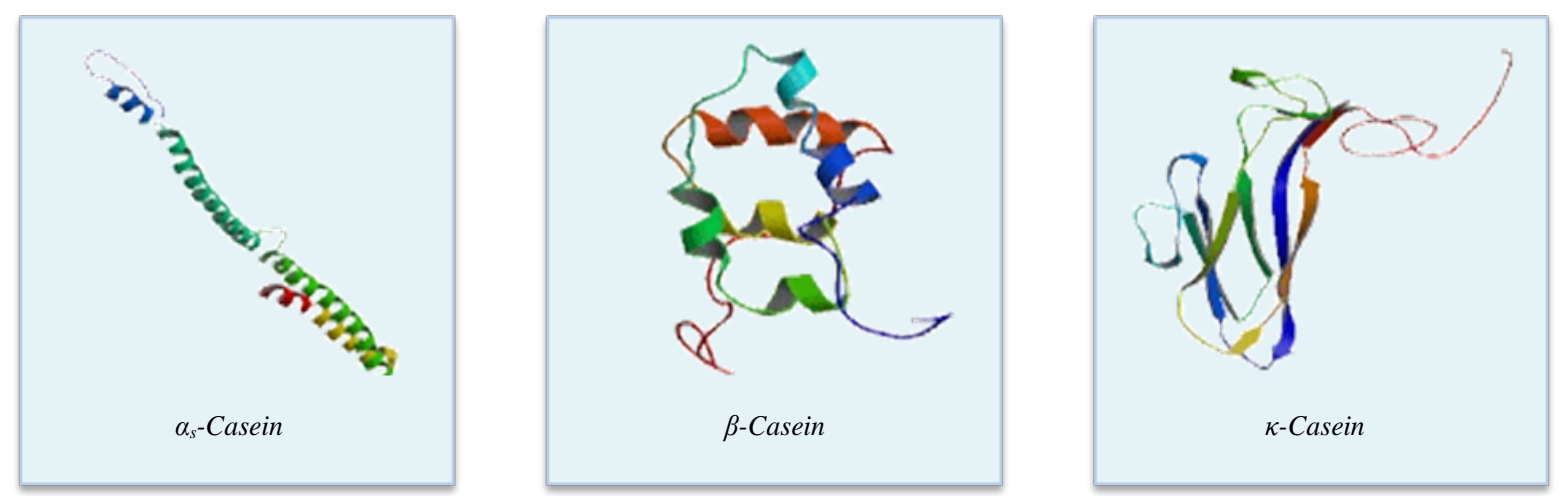

Figure 9. Protein structure of caseins [34].

contribute to their high surface activity, which gives them good foaming and emulsifying properties. Casein functional properties are significantly affected by changes in $\mathrm{pH}$, method of preparation, ionic strength and nature of the salt ion [37].

Regarding the isolated proteins from casein, $\beta$-casein has very high surface activity and may find applications as a high-quality emulsifier or foaming agent. The fortification of milk with $\beta$-casein improves its cheese making properties. This protein is also an attractive ingredient for the manufacture of bovine milk-based infant formulae that more closely mimic human breast milk, which has a higher ratio of $\beta$-casein. $\kappa$-casein might be a useful additive for certain milk products [36]. Nevertheless, the casein proteins find their major application in the production of biologically active peptides, which will be described in subsequent sections.

Currently, the Codex Alimentarius includes a Codex standard covering the identity, composition, labelling 
and quality of edible casein products intended as ingredients in food (CODEX STAN 290-1995) [38].

\subsubsection{Whey Proteins}

The whey protein fraction consists of approximately 50\% $\beta$-lactoglobulin, 20\% $\alpha$-lactalbumin, serum albumin, immunoglobulins, lactoferrin, transferrin, and the proteose-peptone fraction. Regarding their structure (Figure 10), whey proteins are compact globular proteins whose intramolecular folded structure is the result of disulfide bonds between cysteine residues, which buries the hydrophobic residues into the molecule. For that reason, whey proteins do not interact with other proteins. These proteins exist as individual units dissolved in the water phase of milk and stay in solution (unless denatured) over a wide range of $\mathrm{pH}$. They can be denatured by heat, what produces breaking and randomization of the stabilizing disulfide bonds, and exhibit heat-induced gelation [39].

Physical, chemical and structural properties of whey proteins determine their functional properties. As the primary food application of whey proteins is as emulsifiers, the optimum conditions under which they act have been extensively studied. Some influential factors are processing conditions, the method of isolation, environmental conditions (e.g., pH, temperature, ionic strength, etc.), and interaction with other food components. Furthermore, its ability to form gels capable of holding water, lipids, and other components while providing textural properties makes them perfect to be used in processed meat, dairy and bakery products. Regarding its foaming properties, they mainly depend on the degree of the protein denaturation [39].

Whey protein products are produced for food, cosmetic and pharmaceutical sectors. There are diverse types of whey protein products (Figure 11): whey protein concentrate (WPC) (which contains $25 \%$ - 80\% protein), whey protein isolates (WPI) (containing $\geq 90 \%$ protein), whey protein hydrolysate (which will be commented in the following section), $\beta$-lactoglobulin, $\alpha$-lactalbumin and protein-peptone fraction [39] [40].
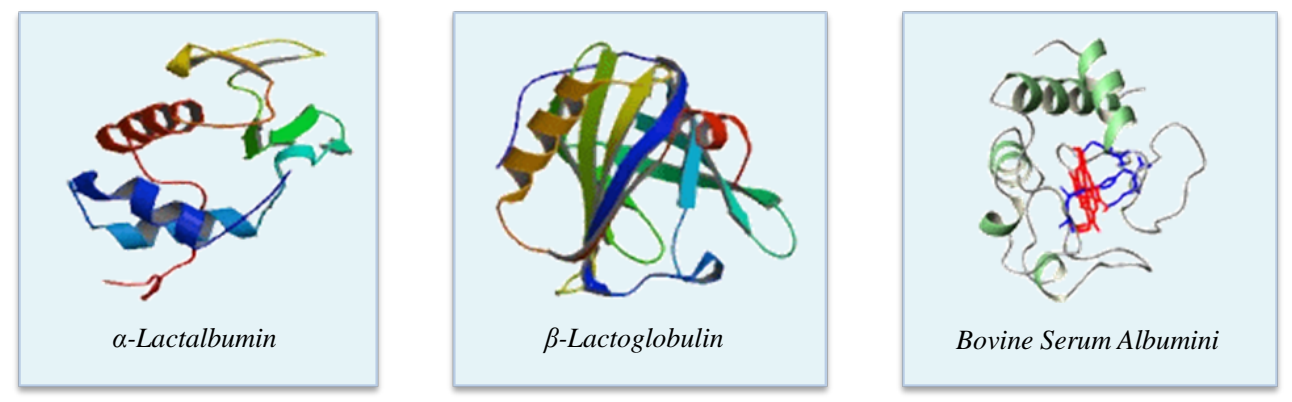

Figure 10. Protein structure of the main whey proteins [34].

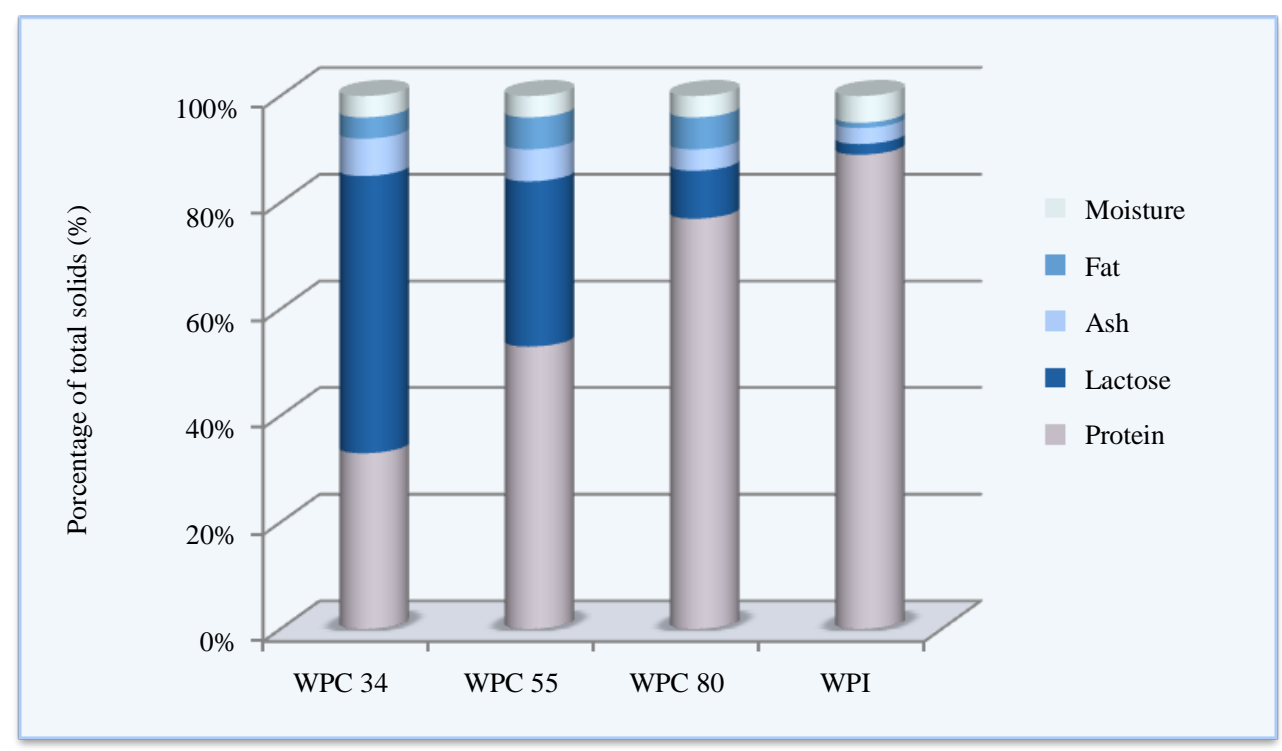

Figure 11. General composition of WPCs. 
As referred above, WPC can be obtained as a by-product of cheese making or from skim milk, Figure 12 summarizes the main steps to obtain WPC through different routes.

Depending on their source, WPC have different flavor and appearance, WPC from the production of cheese is more colored than the one obtained from milk. A solution of milk-derived WPC has a clear appearance, while using cheese-derived WPC is very milky and cloudy. This is due to the higher fat content of the second (Figure 13). The presence of glycomacropeptide only in cheese-derived WPC is another difference.

As well as for caseins, the Codex Alimentarius includes a Codex standard of whey powder for direct consumption or further processing (CODEX STAN 289-1995) [38]. It was also affirmed as "generally recognized as safe" (GRAS) (21CFR184.1979).

WPC containing 34\% - 35\% protein (WPC35) is also rich in lactose and minerals. It has good emulsification properties, is highly soluble and has a mild dairy flavor. This product is used in the manufacture of yogurt, processed cheese, infant formulae, and in various bakery applications. WPC is also marketed for use in stews and sauces because of their thickening properties as well as nutritional benefit. WPC with $\sim 80 \%$ protein (WPC80) has lower carbohydrate content and is characterized by good gelation, emulsification and foaming properties. WPC80 is an excellent ingredient for sports nutrition and weight management products as well as for meat products, thanks to its high gel strength and good water-binding properties [40].

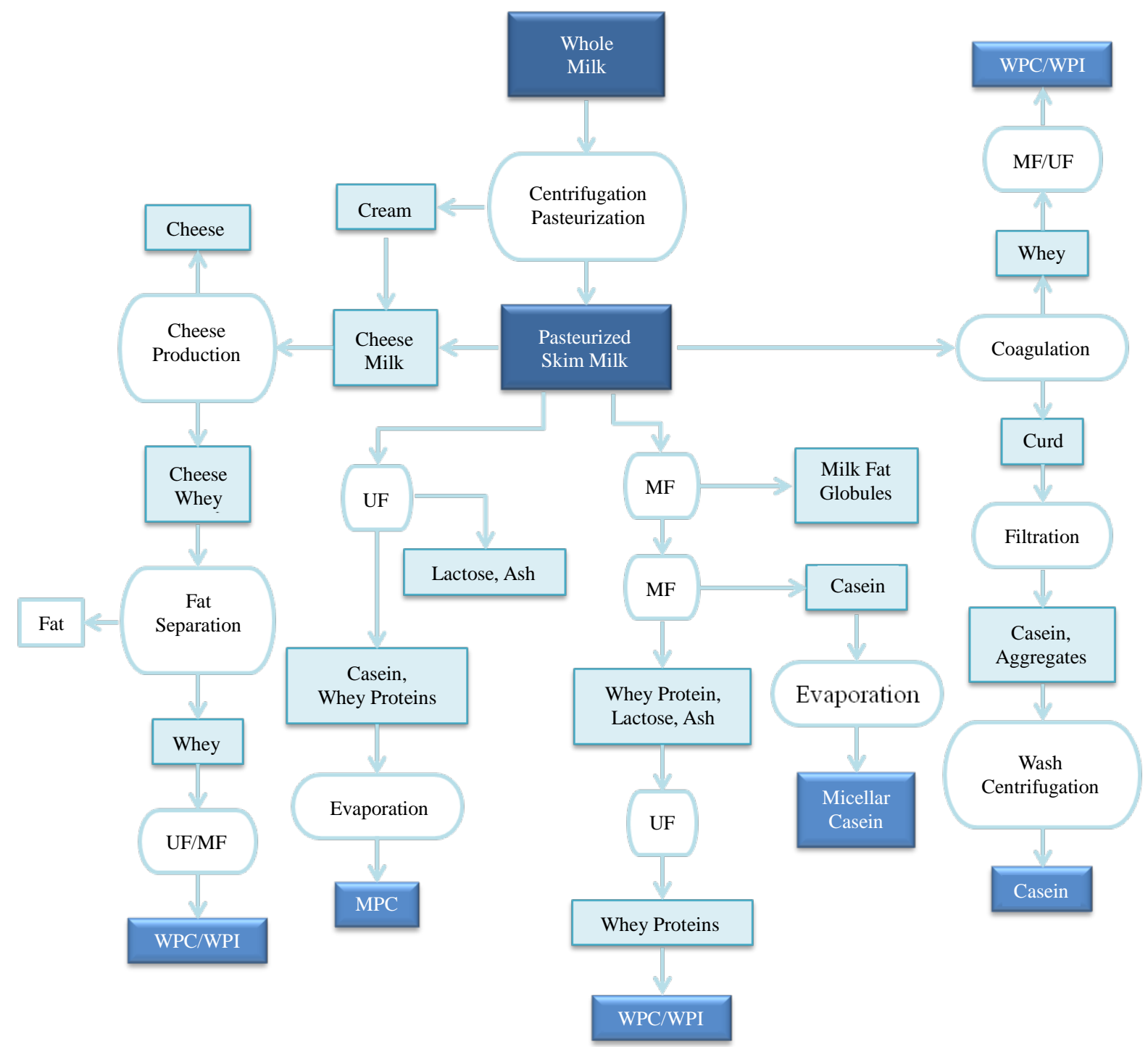

Figure 12. Different processes of manufacture of whey products (UF, MF Ultra and Micro Filtration). 


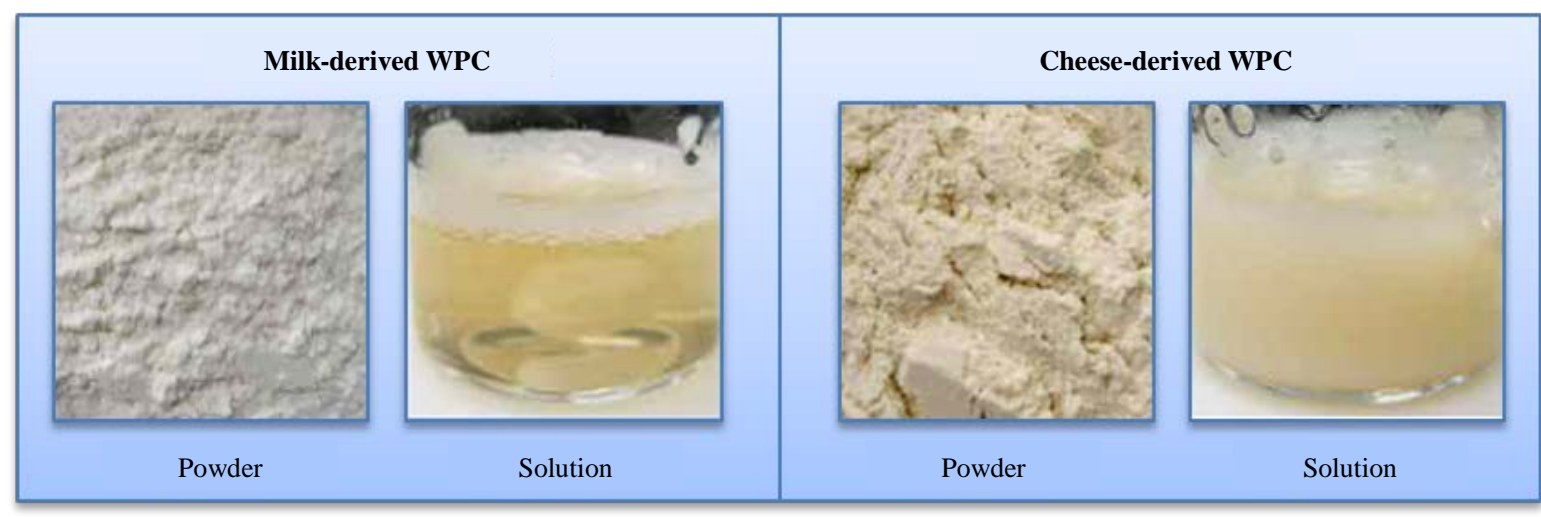

Figure 13. Appearance of WPC from different sources, powdered and in solution.

WPI contains $~ 90 \%$ protein the remaining $4 \%-6 \%$ of the ingredient is a combination of water, fat, lactose, and ash. It is used extensively in nutritional supplements, sports and health drinks, and protein-fortified beverages. Its high protein content makes WPI and ideal water-binding, gelling, emulsifying and foaming agent [40].

$\alpha$-lactalbumin has a molecular weight of $14.2 \mathrm{kDa}$ (Dalton) and an isoelectric point between 4.2 and 4.5. This protein has significant nutritional properties and is associated with some positive health benefits. Its good protein digestibility and amino acid composition are considered to be optimal to be used in infant formulae. It is relatively rich in tryptophan, an essential amino acid which is known to have a positive effect on satiety, mood, sleep and cognitive performance. $\alpha$-lactalbumin also possesses bactericidal or antitumor activity. In addition, synthesis of $\alpha$-lactalbumin nanoparticles and nanotubes as drug and food delivery systems has been studied [41] [42]. Application of concentrated $\alpha$-lactalbumin powder in preparing health-care anti-anoxia beverage has been proposed [43].

Native $\beta$-lactoglobulin is a globular protein $(18.4 \mathrm{kDa})$ with defined secondary and tertiary structure. This protein possesses a high nutritional value and interesting technological properties, but at the same time it is considered one of the major allergens in milk whey. Therefore, eliminating $\beta$-lactoglobulin from milk whey is very important in the dairy product industry [44]. Despite its allergenic potential, food applications and studies concerning emulsifying and foaming properties of $\beta$-lactoglobulinhave been reported [45]-[47].

Proteose-peptone (PP) is a heat-stable and acid-soluble protein fraction, a mixture of heterogeneous proteins and peptides that can be divided into two groups. The first group, the non-hydrophobic fraction, consists of peptides resulting from natural proteolysis of caseins and identified as components PP5, PP8-fast and PP8-slow, highly soluble. The second group of proteins comprises the hydrophobic fractions of glycoproteins whose main component is called PP3 [48].

The techno-functional and biological properties of proteose-peptone fraction are thermal stability, emulsifying and foaming properties, inhibition of spontaneous lipolysis in milk and antibacterial, antiviral and anticarcinogenic activities [49]. The good emulsifying capacity of proteose-peptone fraction as functional ingredient in icecream production allows the reduction or total elimination of the use of emulsifiers such as monoglycerides and diglycerides [50]. It has been reported that the purified PP3 has a higher emulsifying activity than the total unpurified proteose-peptone fraction [51].

Faure et al. [52] patented a method for the industrial production of proteose-peptone enriched extract from whey protein concentrate or whey protein isolate as opposed to skimmed milk, a more expensive raw material. They proposed several uses of these extracts, e.g. in food products and supplements, in nutritional, pharmaceutical and/or cosmetic compositions, as emulsifier or as foaming agent, and/or for low fat products.

Not only milk proteins, but proteins in general are important ingredients in the food industry and the demand for protein-enriched food formulations is increasingly growing. Proteins provide amino acids that are required for growth, functioning and cellular maintenance of the human body. However, their composition is different depending on the source; hence their potential to meet the needs of the human body is also different.

The quality of proteins can be determined by various methods. Protein efficiency ratio (PER), which "measures the weight gain of growing rats when being fed the test protein”. This method only reflects the amino acid requirements for the rat rather than the actual human amino acid requirements. Another method to compare the 
quality of various proteins is known as protein digestibility corrected amino acid score (PDCAAS) and based on the amino acid requirements of humans. According to this method, "an ideal protein that meets all the essential amino acid requirements of human body will have a value of 1.0". Moreover, the biological value (BV) provides "a measurement of how efficient the body utilizes protein consumed in the diet". Table 2 summarizes the quality of proteins from different sources [53].

Vegetables proteins have a lower biological value, this is due to the presence of trypsin inhibitors, lectins and tannins, which hamper the hydrolysis of proteins and hence the obtaining and final absorption of amino acids. Besides, these proteins lack of one or more of the essential amino acids. However, vegetable proteins, may be combined to provide for all of the essential amino acids, avoiding animal sources and with a lower content of saturated fat. These proteins also include other nutrients such as phytochemicals and fiber. For instance, soy proteins provide protease inhibitors, phytosterols, saponins, and isoflavones that are beneficial for cardiovascular health. Milk proteins, however, provide high levels of the essential and branched chain amino acids. These proteins also possess many beneficial bioactivity properties and are a rich source of minerals and vitamins [53].

\subsection{Enzyme Modification of Milk Proteins}

Enzymatic tailoring of proteins by hydrolysis or cross-linking is attempted in order to improve their functionality and stability.

\subsubsection{Enzymatic Hydrolysis of Milk Proteins}

The enzymatic hydrolysis of milk proteins enables tailoring their functional properties to meet individual requirements of food formulations. To achieve that, the selection of the right proteolytic enzyme (such as pepsin, trypsin, neutrase, chymotrypsin, and plasmin), time and environmental conditions for hydrolysis and degree of hydrolysis is crucial. Controlled hydrolysis may enhance some functional properties and simultaneously be detrimental to others [54]. Functional properties that can be affected by hydrolysis of proteins are surface hydrophobicity, gel strength, emulsion stability, emulsification capacity, foaming and solubility [55].

Partial hydrolysis of proteins may improve their functionality, but excessive hydrolysis could negatively affect it. In addition, it is generally accepted that higher hydrolysis degrees produces bitterness [55]. Enzymemodification resulted in an adverse effect on the emulsifying functionality of milk proteins (whey protein concentrate, whey protein isolate and casein) in $\mathrm{O} / \mathrm{W}$ and mayonnaise-like emulsions, producing bitterness [56]. However, this was probably due to the inappropriate selection of the hydrolysis procedure.

Food-grade proteolytic enzymes are obtained from different sources (animal, bacterial, fungal or plant), having different $\mathrm{pH}$ and temperature optima and hydrolyzing a variety of peptide bonds. Therefore, depending on the specificity of the enzyme, environmental conditions and extent of hydrolysis, a wide variety of peptides can be generated [54]. Caseins, because of their flexible random structures, are more susceptible to hydrolysis compared to the whey proteins, with compact globular structure [55].

Milk proteins concentrates have limited use in some applications, especially in beverages, because of their poor solubility, which is an important factor in determining their functional properties. Hydrolysates show improved solubility what broadens its range of applications [55]. In general, the hydrolysates have a higher rate of diffusion to the oil/water interface and cover a larger area of the interface than the native protein [57] [58]. Furthermore, peptides have a high nutritional value, are easy to digest and absorb, and are less allergenic.

Table 2. Comparisons of quality of different proteins.

\begin{tabular}{cccc}
\hline Protein type & PER & PDCAAS & BV \\
\hline Whey protein & 3.2 & 1.00 & 104 \\
Casein & 2.5 & 1.00 & 77 \\
Milk & 2.5 & 1.00 & 91 \\
Soy protein & 2.2 & 1.00 & 74 \\
Wheat gluten & 0.8 & 0.25 & 64 \\
Beef & 2.9 & 0.92 & 80 \\
Egg & 3.9 & 1.00 & 100 \\
\hline
\end{tabular}


The influence of hydrolysis on several applications has been studied. For example, the neutrase treatment of milk proteins to prepare yoghurt showed an improvement in body, texture and flavor, a faster rate of acid development and a reduction in setting time [59]. Protein hydrolysates, from casein and whey protein, are increasingly finding commercial applications in a number of formulated foods such as; high-energy supplements, geriatrics foods, weight-control foods and hypoallergenic infant formulae. The growing trend towards low-calorie and low-fat diets has led to the use of modified proteins as fat replacers [54]. WPI hydrolysates have been used as emulsifiers to produce nanoemulsions for food applications [60].

Some studies have been carried out to elucidate the functional and biological properties of polypeptides obtained from hydrolysis of milk proteins, including interactions between proteins and their hydrolysates [61]. The stabilizing properties of polypeptides from $\alpha_{\mathrm{s} 1}$-casein can in principle outperform the properties of the protein. However, the hydrolysis of the protein also produces undesired polypeptides that interfere with the optimal function of the desired ones. The purification of the desired fragments enhances their emulsion stabilizing properties [62]. It is clear that a deeper understanding of the structure-function relationship of peptide behavior both in model and real food systems is essential to increase the use of enzymes in enhancing the functionality of food proteins [54].

\subsubsection{Cross-Linking of Milk Proteins}

Cross-linking of food proteins using enzymes such as peroxidase, tyrosinase, transglutaminase, and laccase, can modify their solubility, hydration and heat stability, as well as their gelation, rheological and emulsifying properties [63]. The susceptibility of a protein to cross-linking depends on its macromolecular structure. Individually, both the caseins and whey proteins are good substrates, but in a mixed solution caseins are more susceptible to cross-linking than native whey proteins [64], as referred for the hydrolysis. Some structural modifications of whey proteins, such as heat denaturation or chemical modification, make them more suitable to be cross-linked, either with caseins or other whey proteins [65] [66].

Transglutaminase (TG) is one of the most widely used proteins for cross-linking of milk proteins. In a generic TG reaction, the $\gamma$-carboxamide groups of the glutamine residues act as acyl donors, and the $\varepsilon$-amino groups of lysine residues act as acceptors (Figure 14). Enzymatic cross-linking of individual milk proteins and other proteins with TG has been shown to increase heat stability and has a considerable effect on their emulsifying properties [67] [68].

The effect of the degree of enzymatic cross-linking of milk proteins was studied [69]. Higher emulsion stabilities were observed at low degrees of cross-linking compared to native proteins or extensive cross-linking. On the other hand, creaming stability of emulsions was improved even at high degrees of cross-linking compared to native proteins; this was attributed to the increased viscosity of the medium or changes in the adsorbed layer.

It has been reported that properties of emulsions containing cross-linked $\alpha$-lactalbumin were influenced by the sequence of cross-linking and emulsification. While cross-linking before emulsification decreased the stability of the emulsion, due to a lower rate of protein adsorption and restricted ability of protein to unfold at the oilwater interface, this stability was improved when cross-linking was carried out after emulsification [70]. In addition, due to the partial unfolding of globular proteins when adsorbed at the oil-water interface, cross-linking after emulsification is easier and a higher increase in surface viscosity is reached [71]. In sodium-caseinate-stabilized emulsions, it was found that cross-linking by transglutaminase before emulsification significantly improved the emulsion stability. In contrast, cross-linking after emulsification produced a great loss of long-term stability due to droplet coalescence [72].

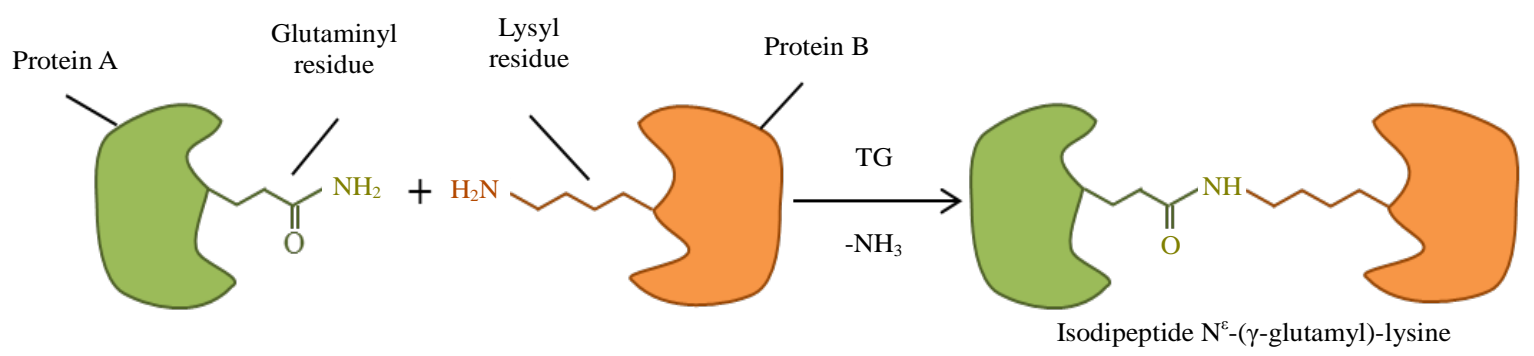

Figure 14. Transglutaminase-catalyzed protein cross-linking. 
The modification of whey protein using an immobilized form of microbial transglutaminase, besides the well-known benefits of immobilized enzymes such as an easy separation of catalyst and substratereutilization of the enzyme ornoneed for a downstream inactivation treatment; allowed to control the extent of cross-linking. Additionally, the combination of recombinant fusion proteins and immobilized enzyme technologies was also studied. In both cases, intrinsic and apparent viscosity increased, gel point temperature decreased, and stronger, more brittle gels were formed [73] [74].

Regarding applications, cross-linking may be used for stabilizing products such as yogurt, whipping cream, fresh cheese and novel milk products. Yoghurt from lactoperoxidase-, laccase- and glucose oxidase-treated milk was characterized by a minor acidity and whey drainage as well as by a more soft, homogeneous and creamy consistency than yoghurt from untreated milk [75]. It has also been reported that transglutaminase treatment of proteins improved gel strength and increased viscosity of yoghurt as a result of improved water-holding properties [76]. In addition to higher gel strength in yoghurt samples, a lower whey syneresis was observed [77]. Yoghurt samples from transglutaminase-treated milk showed better sensory characteristics, and were described as being more creamy, indicating that cross-linking may be a very useful tool for low-fat fermented products [77].

\subsection{Milk Proteins as a Source of Bioactive Peptides}

The concept of bioactive peptides derived from food proteins was developed in the 1980s, since then, a worldwide interest for bioactive peptides is growing in the scientific community. This suggests the potential use of biopeptides as nutraceuticals and ingredients of functional foods to promote health and reduce the risk of diseases. Bioactive peptides, defined as "specific protein fragments that have a positive effect on body functions or conditions and might ultimately influence health", can be released from their parent protein by enzymatic hydrolysis using food-grade enzymes, during microbial fermentation by proteolytic cultures or during gastrointestinal digestion [78]. Moreover, recombinant DNA technologies are being investigated for obtaining large quantities of highly purified peptide fractions [79].

The most common way to produce bioactive peptides is through enzymatic hydrolysis of proteins; this process is analogous to that stated above for the enzymatic modification of proteins. For that reason, the bioactive properties of the peptides are influenced by the same factors (enzymes used, hydrolysis time, degree of hydrolysis, pretreatment of the protein,...). In order to obtain high-yield peptide products with potent bioactivity, further processing, such as fractionation and concentration, of the enzymatic protein hydrolysates is needed [61] [80].

Major milk proteins (caseins, $\alpha$-lactalbumin, $\beta$-lactoglobulin) constitute an important source for bioactive peptides with a wide range of physiological properties. Milk-derived bioactive peptides were shown to have antihypertensive, antithrombotic, antimicrobial, antioxidant, immunomodulatory, antipyretic, opioid, mineralbinding properties and anticarcinogenic activities (Figure 15). Numerous fragments of caseins and whey proteins have been identified as bioactive peptides and categorized according to their particular health beneficial potentials [79] [81]-[83]. Phelan et al. published a comprehensive review regarding biological effects of casein-derived bioactive peptides, their application in industry and safety aspects and regulations [78].

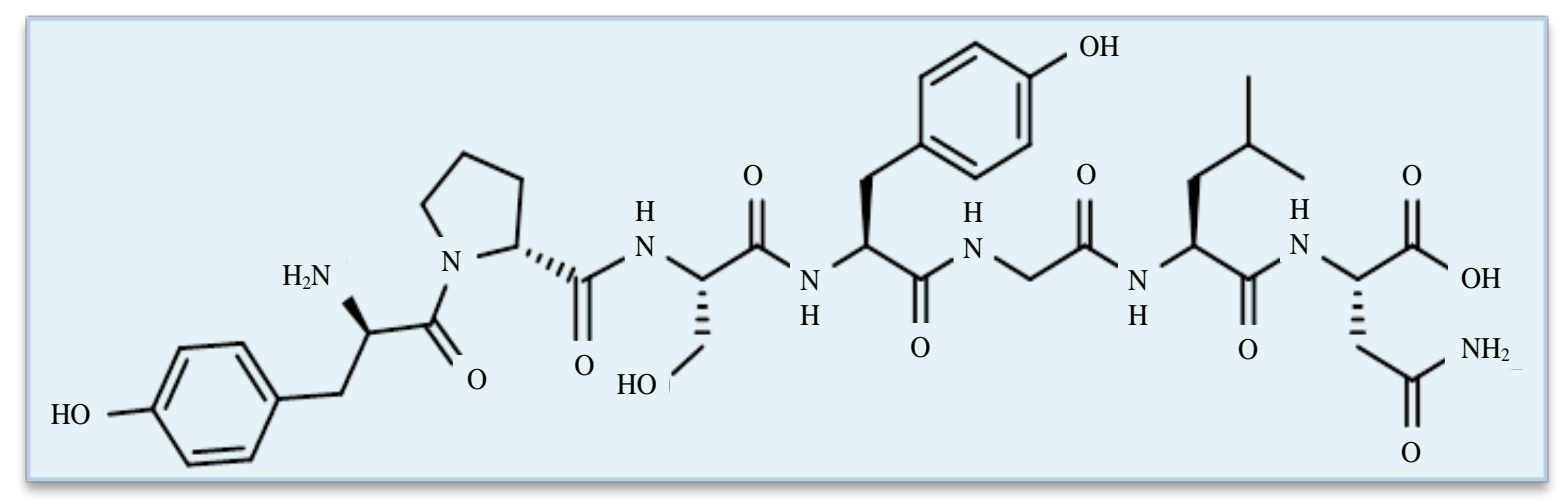

Figure 15. Chemical structure of a bioactive peptide; casoxin Aderived from $\kappa$-casein, fragment (35-41), with opioid antagonist activity. Aminoacid sequence: Tyr-Pro-Ser-Tyr-Gly-Leu-Asn [84]. 
Most of the studies to identify milk bioactive peptides as well as to study their bioavailability and molecular mechanisms of action have been carried out in vitro [80] [81] [85]. The main problem is that in vivo pharmacological effects of peptides would hardly be equivalent to their in vitro bioactivity because other variables come into play, such as absorption, bioavailability, and degradation of peptides by physiological enzymes [86]. Microencapsulation and nanoemulsion have been explored for the administration of bioactive peptides, to enhance and control their stability and absorption [60] [87].

Much of the work to date has focused on milk, cheese and other dairy products as sources of bioactive proteins and peptides, still, interest in other sources of food-derived bioactive peptides is growing. Some of these sources are fish species such as sardines, tuna, bonito and salmon, as well as other animal products such as blood, eggs and gelatin. Plants are also potential sources, for instance: wheat, rice, soya, pumpkin and mushrooms [82]. A quantitative structure-activity relationship (QSAR) based in-silico method was proposed for the prediction of food protein sources that can yield bioactive peptides [80]. To achieve that goal, details of the structure-function properties of active sequences should be known. The biological effects attributed to the consumption of bioactive peptides and their possible sources are numerous and continuously increasing.

Although these substances are expected to be safe because they have been consumed for centuries and therefore have the GRAS status, there are a number of issues which must also be considered, such as the potential for allergy or intolerance [82]. Those aspects strongly depend on the concentration in bioactive peptides. Very low concentration might not be sufficient to provoke the desired benefit, while too high concentration might cause negative effects and be unsafe.

Food products containing bioactive peptides are commercially available in Japan, Europe, and the United States or under commercial development in these countries [80]. Calpis ${ }^{\circledR}$ (Japan) and Evolus ${ }^{\circledR}$ (Finland) are used by their antihypertensive properties. Other commercially available bioactive peptides are whey protein hydrolysateBioZate (USA), containing fragments derived from $\beta$-lactoglobulin, and C12 peptide ${ }^{\circledR}$ (Holland), used as a food additive and enhanced antihypertensive peptide obtained by hydrolysis of casein. Other casein derived peptides (phosphopeptides, $\beta$-casomorphins) have already found interesting applications as dietary supplements and pharmaceutical preparations [78] [81].

The regulatory framework is as follows [88]:

- Japan, first country to adopt regulations for allowing claims on functional foods in 1991, FOSHU: Foods for Specific Health Use.

- United States, Food and Drug Administration (FDA) is charged with the responsibility for the regulation of dietary supplements, dietary supplements produced before 1994 are assumed safe, whereas the safety of those marketed after 1994 is the responsibility of the manufacturer.

- European Union, there is no appropriate legislation for functional foods or nutraceuticals as a distinct category of foods. The general food law regulations are applicable to all foods. Only regulations concerning the use of casein and caseinates in the manufacture of cheeses have been established by the European Commission 760/2008 of July 31, 2008.

- Canada, bioactive peptides could be sold as natural health products or as an ingredient of functional food. Natural health products fall under the Natural Health Products Regulations of the Food and Drugs Act which came into effect in 2004.

Based on the cited references; although a lot of information exists on the production, processing, potential health benefits and mechanisms of action of milk protein-derived peptides [80] [83], aspects such as healthpromoting effects, molecular mechanisms of action and bioavailability in humans should be more deeply evaluated in the near future. Furthermore, the safety of these biopeptides needs a profound understanding. As global regulations on using bioactive peptides are insufficient, the development of accurate standardized methods for their characterization and quantification and clinical trials to assess their efficacy, intolerance, and allergenicity should provide valuable information for the establishment of appropriate policies regarding acceptable scientific validation of efficacy and health claims [88]. Those aspects have been reported in the cited reference.

\subsection{Use of Whey Proteins to Obtain Bioemulsifiers}

Bioemulsifiers are surface-active agents synthesized by microorganisms: bacteria, fungi and yeast. These substances are characterized by their environmentally friendly nature, since they are easily biodegradable and have low toxicity. Moreover, they have good surface activity, emulsifying ability and antimicrobial properties. For all 
those reasons, the interest in these bioemulsifiers has been increasing as an alternative to chemical surfactants [89].

One of the most interesting aspects of bioemulsifiers for food industries is the possibility of using their byproducts or residues as substrates. The main alternative sources for bioemulsifier production comprise oily residues, milk and distillery wastes, and carbohydrate-rich residues [89]. Whey milk and cheese whey have been reported as potential substrates in the production of bioemulsifiers by diverse surfactant-producing microorganisms [90]-[92]. Cheese whey as a waste product from cheese production is known, as reported in cited references, for being a pollution problem in the dairy industry, so its valorization through the production of bioemulsifiers represents both a solution for the environmental problem and an economic incentive.

The pathogenic nature of many microorganisms to produce bioemulsifiers restricts their range of uses, especially in the food industry. Byproducts from microorganisms with the GRAS status can be applied in the food and pharmaceutical industries Therefore, bioemulsifiers obtained from GRAS microorganisms would not represent a risk, hence being of great interest in food and medicine applications [93].

Regardless of their interesting properties, the use of bioemulsifiers has still not reach a large scale since many regulations concerning the approval of new food ingredients are required by governmental agencies, currently there are not specific legal regulations for this substances. Their eventual toxicological aspects should be clearly identified before declaring them safe for food utilization [89]. Nevertheless, an increasing number of patents claiming their use as additives for food, cosmetics and pharmaceutical products demonstrates the global interest in their exploitation [94].

\section{Fat Fraction}

Milk fat has a very complex fatty acid composition. Over 400 individual fatty acids have been identified in milk fat. However, approximately 15 to 20 fatty acids make up 90\% of the milk fat [9]. The major fatty acids in milk fat are straight chain fatty acids that are saturated and have 4 to 18 carbons (4:0, 6:0, 8:0, 10:0, 12:0, 14:0, 16:0, 18:0), monounsaturated fatty acids $(16: 1,18: 1)$, and polyunsaturated fatty acids $(18: 2,18: 3)$. The fat globules in milk consist of a triglyceride core, surrounded by a protein and phospholipid membrane that stabilizes the globules in the serum (water) phase of milk, called the milk fat globule membrane.

\subsection{Milk Fat Globule Membrane}

\subsubsection{Composition and Properties of the Milk Fat Globule Membrane}

The milk fat globule membrane (MFGM) has a complex structure (Figure 16) and contains characteristic polar lipids and membrane-specific proteins. Fat in the core of the globules is mainly composed of neutral triacylglycerides (62\%) whereas the lipid fraction in the MFGM mainly comprises phospholipids, highly bioactive molecules, with scientific evidence on its nutritional benefits [95]. Those are mainly sphingolipids, especially sphingomyelin, and glycerophospholipids such as phosphatidylethanolamine (PE), phosphatidylcholine (PC), phosphatidylinositol (PI) and phosphatidylserine (PS). The protein fraction of MFGM also has a specific composition, composed mainly of glycosylated proteins with specific technological and nutritional properties [96]. Therefore, due to their properties, origin and structure, MFGM polar lipids and proteins could be valuable emulsifiers or stabilizers. Knowledge on the composition and properties of the MFGM is increasing and MFGM components have been isolated from diverse sources by different purification procedures, extensively reviewed by Dewettinck et al. [95].

Their amphipathic nature and original function in stabilizing the fat globules in whole milk make MFGM fragments to be considered as efficient and natural emulsifiers [98] [99]. Additionally, because of its nutritional properties, components of the MFGM are suitable to be exploited as a novel ingredient for the development of new functional food products [95].

The emulsifying properties of MFGM materials are strongly dependent on their composition in polar lipids and proteins, as well as their possible interactions. The starting material, processing, heat treatments and purification have a clear influence on the composition of MFGM isolates and, consequently, on their technological functionalities [100]. The composition of MFGM materials must be carefully standardized before being used in food products in order to maintain their properties.

Several authors have gathered and reviewed the different health-enhancing functions attributed to MFGM components [95] [99] [101]. For example, polar lipids have been reported, in the cited literature, to have positive 


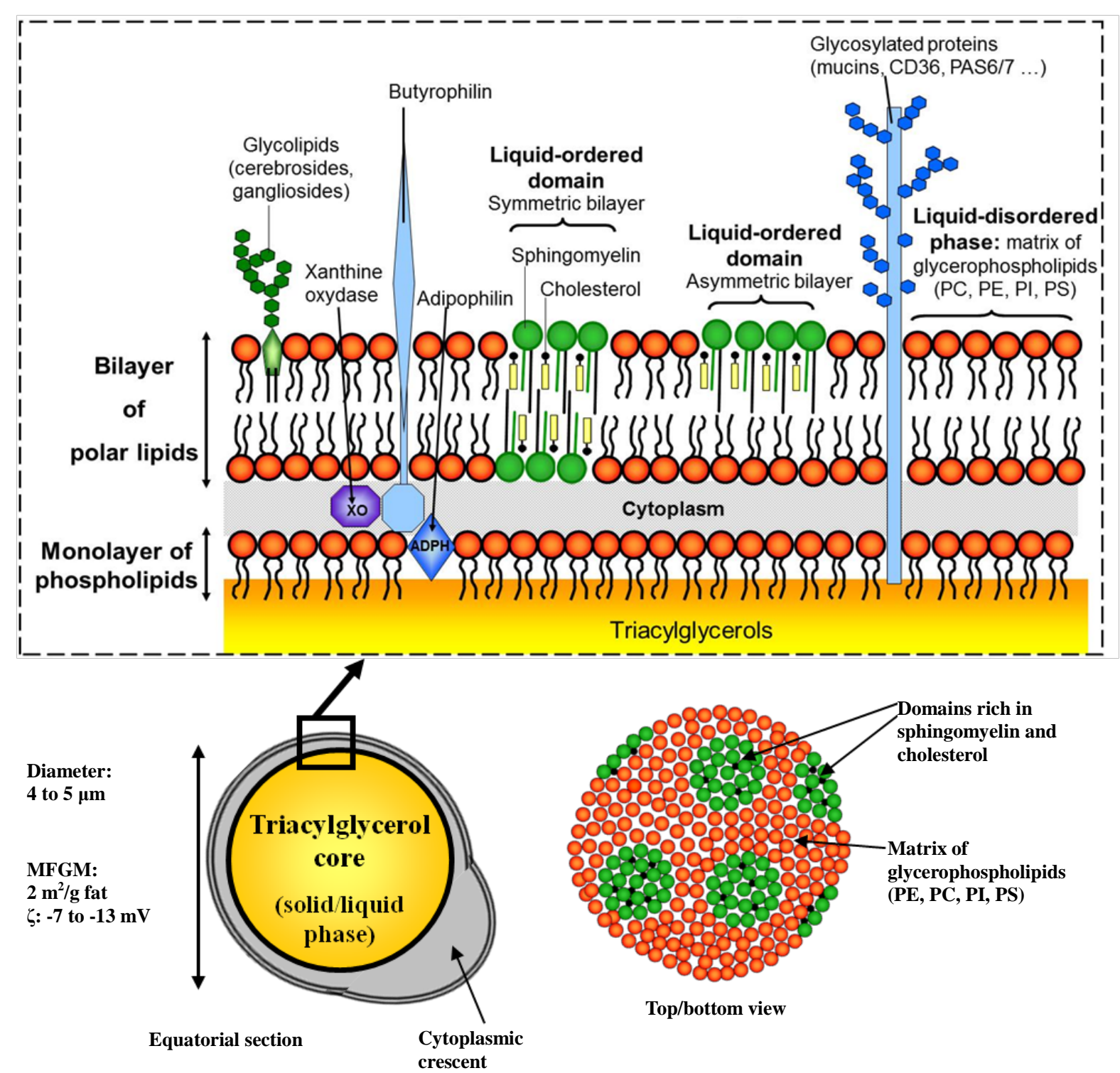

Figure 16. Structure of milk fat globules and schematic representation of the milk fat globule membrane. Adapted from [97] with permission from the author.

effects on alzheimerdisease, anticarcinogenic, mitogenicand anticholesterolemic activities, bacteriostatic and bactericidal capacities, etc. As for MFGM proteins, they have been found to have anticarcinogenic, antibacterial and antiviral effects, influence in the pathogenesis of autistic behavior and in the development of multiple sclerosis, among others; as stated in [95]. In contrast, some negative health implications have also been reported for MFGM materials [102]. However, as referred above for bioactive peptides, most of the studies to determine functional aspects of MFGM are based on in vitro experiments, so the translation of those results to the effects on human body should be carefully considered. It can be concluded that further research in this field should be carried out.

\subsubsection{Phospholipids from the Milk Fat Globule Membrane}

Milk contains approximately $0.01 \%$ - $0.04 \%$ (w/w) phospholipids, of which phosphatidylcholine, phosphatidylethanolamine, and sphingomyelin together make up 80\% - 90\% (Figure 17). The rest consists of phosphatidylserine and phosphatidylinositol. Despite the modest concentration, the phospholipids have a critical role in stabilizing milk fat globules against coalescence. 

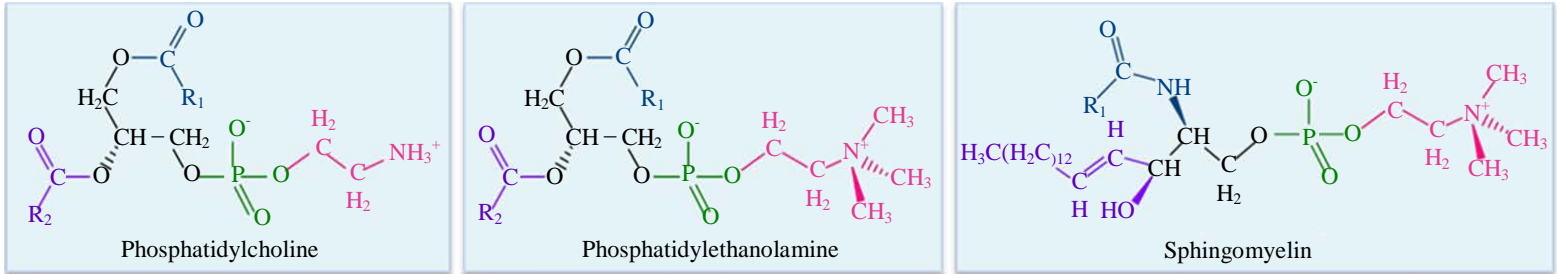

Figure 17. Chemical structures of the most important phospholipids contained in milk.

Phospholipids in general consist of a glycerol-3-phosphate molecule esterified at its carbon 1 (sn-1) and carbon 2 (sn-2) positions to non-polar fatty acids and at its phosphoryl group to a polar head group (a nitrogenous base, a glycerol, or an inositol unit).

As commented above, polar lipids from the MFGM are implicated as having various benefits for human health. Phospholipids in particular are considered to have positive effects on Alzheimer patients, molecular transport systems or stress responses, restoring memory, improving exercise capacity, protecting organs against toxics or the development of cancer diseases [95] [101].

Thanks to their unique emulsification properties, milk phospholipidscan be used in a variety of foods such as frozen desserts, bakery products, pumping hams and other meats [103]. They are applied as baking improvers to ameliorate fat dispersion and antistaling, as additives to chocolate to reduce viscosity and prevent crystallization, as wetting enhancer of instant products, and as stabilizers of margarine to prevent spattering and browning. Milk phospholipids are also used as drug delivery carriers, as fat liquoring for leather fatting, as raw materials for the production of ceramides and for the production of liposomes [95].

There are some commercial products such as Lacprodan ${ }^{\circledR}$ PL-20 (Arla Foods Ingredients), is a milk protein concentrate enriched with phospholipids and gangliosides. The profile of phospholipids, similar to that of human milk makes it perfect for use in infant formulae. In addition to nutritional benefits, Lacprodan ${ }^{\circledR}$ PL-20 offers additional advantages such as oxidation stability, a milky taste and good emulsifying properties. It is easy to formulate in functional foods, e.g. drinks, chocolate and ice cream as an active health ingredient [104].

The production of milk phospholipids from cheese whey-derived MFGM has been studied and its properties have been compared with soy lecithin [105]. It has been found that the fatty acid profile of milk phospholipids (mainly saturated and mono-unsaturated fatty acids) is more stable than soy lecithin, and it offers better oxidative stability and different functionality. Milk phospholipids are proposed as alternative sources of soy lecithin that can be regarded as a non-GMO (non-genetically modified) product, and that is suitable to people that are allergic to soy products. Moreover, milk phospholipids contain a wider spectrum of complex sphingolipids (sphingomyelins, cerebrosides, globosides, gangliosides or sulfatides), while the sphingolipids of plants are mainly cerebrosides [106].

Although soy still dominates the lecithin source market, as a consequence of growing concerns over the allergies and consumer apprehension regarding the use of GMO soy lecithin, other sources of lecithin and phospholipids, apart from milk, have been researched and introduced in the past decade such as egg and sunflower. A compound annual growth rate of $5.8 \%$ has been estimated for the global lecithin and phospholipids market, reaching more than $\$ 5000$ Million by 2019 with applications in food, nutrition, pharmaceuticals, cosmetics and animal feed, among others; as stated in [107].

\subsubsection{Enzyme-Modification of Phospholipids}

The possibility of enhancing the nutraceutical and other functional properties of milk phospholipids by enzymemodification has been scarcely explored. This is mainly due to the immature knowledge on phospholipases and sphingomyelinases and the low concentration of polar lipids in milk fat [108].

It has been reported that, by the modification of phospholipids by phospholipase Aproducinglysophospholipids (Figure 18), better oil-in-water emulsification properties are achieved compared to the natural properties of the corresponding phospholipids [109]. Higher fat and moisture retention in cheese curd was reported with the partial hydrolysis of phospholipids resulting in a higher production yield [110]. The thermal stability and foaming of a phospholipid-containing whey protein concentrate was increased after treatment with various phospholipases [111]. The hydrolysis of milk phospholipids decreased surface tension and increased foam stability of skim milk and whey [112]. 

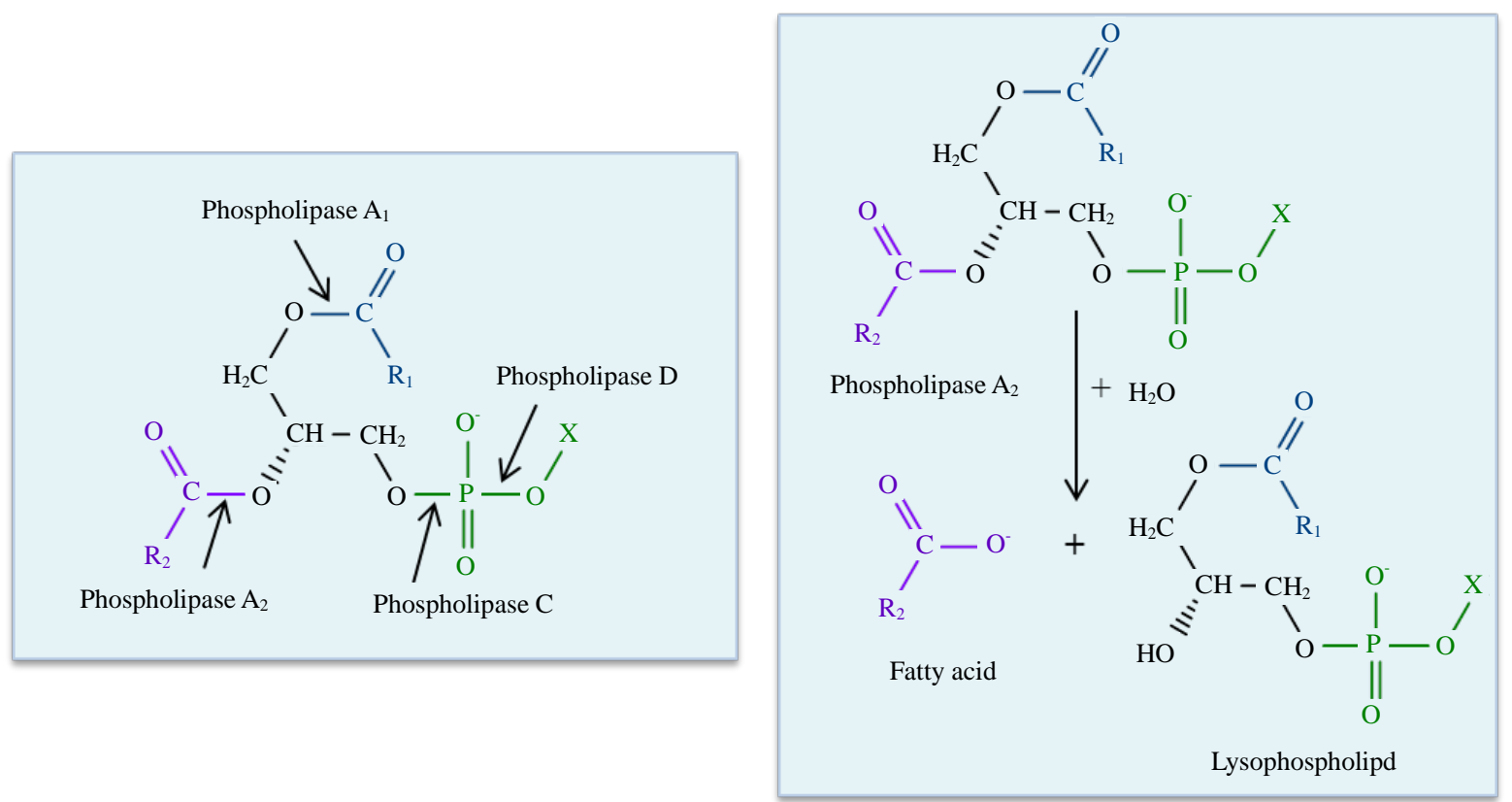

Figure 18. Indication of the sites of hydrolysis of phospholipids by phospholipases type $A_{1}, A_{2}, C$, and D (left). Production of lysophospholipid by action of phospholipase $\mathrm{A}_{2}$ (right).

Phospholipases may be used to improve the production of dairy foods or may have interesting perspectives in the modification of milk or whey fractions to yield dairy-based ingredients with novel functional properties Enzyme-modification of milk phospholipids offers an interesting new tool for tailoring dairy products with altered functionality and could promote the replacement of traditional emulsifiers [112].

\section{Alternative Non-Food Applications of Milk Ingredients}

Although this review has been focused on the uses of milk components in the food industry, it is worth taking into consideration other milk non-food applications. Commercial non-food applications of casein proteins include textile fibers, adhesives, packaging films, biomaterials, plastics and additives in paints, concrete, cement, cosmetics and rubber. Compared to caseins, whey proteins are not so exploited in non-food industries, surfactants in cosmetology and pharmacology, and manufacture of protective films or coatings are some examples. Regarding the milk fat fraction, it is used in the manufacture of emollients and fatty acids.

In the current desired green framework, the most important aspect of non-food applications is the valorization of dairy co-products, hence reducing waste streams to compliance with safety and environmental regulations. Cheese whey, by-product of cheese production, is rich in whey proteins and lactose and some of its value-added applications are: manufacture of fermented products such as methane, ethanol, butanol, organic acid, polysaccharides and yeast biomass [113].

\section{Conclusions}

Dairy ingredients are becoming more and more important in food product innovation and production. The continuous technological and research advances in the milk industry make it possible to capture and tailor the inherent biological and nutritional properties of milk ingredients for a diverse range of applications. Fractionation techniques allow isolating milk ingredients with diverse ranges of purity and there is no doubt that they are critical in the development of new products and ingredients that drive the demand for dairy products. A wide variety of dairy ingredients is commercially available and used not only in dairy foods but in many other products such as confectionery, beverages, cereals, sauces, dressings and sport complements.

Milk proteins are the most maximized components, through the obtaining of numerous formulations of MPCs, WPCs and caseins, with different compositions and applications in a variety of food and pharmaceutical industries. Additionally, the properties of these products are enhanced by their enzymatic modification, hydrolysis 
and cross-linking. Their range of applications is increased by the production of bioactive peptides, a field with almost unlimited research potential. Concerning WPCs, which can be produced from skim milk, are mainly obtained as a by-product in the cheese industry, so their utilization as a valuable product has relevance to environmental concerns relating to whey disposal and hence to the cost of the product. In addition, whey protein from the cheese industry is valorized in the production of bioemulsifiers.

Though milk fat globule membrane can be used as emulsifier itself, its real significance lies in the phospholipid fraction contained into its structure. Milk phospholipids are powerful emulsifiers, besides their unique health benefits, an emerging research field that needs a deeper understanding. Furthermore, the possibility of tailoring those attracting properties by enzyme modification opens up a massive amount of new applications.

Milk proteins and phospholipids compete with similar substances obtained from other sources such as vegetables, especially soy. The main advantage of milk proteins lies on their highest quality proteins, being a perfect source of essential amino acids, while milk phospholipids have the richest combination of sphingolipids with health-enhance effects. In general, milk ingredients are suitable to people that are allergic to soy products and to those that reject GMO products. From the opposite position, they are inapt to people allergic or intolerant to milk products and vegans.

Alternative applications of milk constituents in the non-food area are also essential from the green perspective. The full valorization of those is first and foremost the main focus of interest. Additionally the green factor is part of the most innovative processes, such as transferring dairy technology to vegetable counterparts.

Some final considerations relating to the use of concentrated or modified milk ingredients in the food industry should be mentioned. First, it is necessary to settle clear and specific regulations for these new ingredients, including purity, functional claims and applications. Secondly, the need of standard and regulated in vitro and in vivo procedures to prove their claimed health beneficial aspects, this is particularly important for bioactive peptides and enzyme-modified phospholipids. Even though milk is a safe product, processing or concentration of its components to obtain the desired beneficial properties might eventually cause some adverse health effects. It is clear that a deeper understanding of the functional and nutritional properties of these ingredients will be essential to meet consumer expectations and avoid subsequent problems.

A large spectrum of innovation is outlined by the reviewed art. One may wonder how IP and scientific NPL could be combined to provide synergism of a multiplying dimension. The Bigger Data approach associated with human expert trend analysis and artificial intelligence can definitely help to that regard.

\section{Acknowledgements}

The authors thank:

Benoit Steffenino for some of the illustrative accomplishments yielding notorious interpretational improvements.

Salvadora, co-author, for the outstanding precision and diligence and for her consulting in the field of interest and beyond.

More about the authors:

Serge Rebouillat [Rebooya], Dr. Ing., Dr-ès-Sciences, Certified Prof., Ind. Energetic, Chem/Bio Eng., Rheology, IP: Mediation/Innovation \& Strategy/Management/Valuation.

Salvadora Ortega-Requena, Ph.D., Biotechnologies/Enzyme fundamentals.

\section{Disclaimer}

This article is primarily for educational purposes. Selected cases are strictly illustrative. Neither the author nor the illustrator assumes any liability for any errors or oversights, or for how this article or its contents are utilized or interpreted, or for any consequences resulting directly or indirectly from the usage of it.

Some assessments are intended to educate and raise awareness of some of the complex issues that surround the intellectual property in the field of knowledge extraction from patent documents available, and to assist in the development of practical skills for dealing with inventions in the context of innovation. It does not seek to provide legal, managerial or technical advice on intellectual property related law as such.

This educational material should not be relied upon when taking specific business or legal decisions. Rather, professional advice should be obtained which suits the circumstances in question. This study can by no mean substitute for legal, technical and managerial expert advice. 
The opinions expressed by the writers in this article do not necessarily represent the viewpoints of the companies the authors are employed by.

\section{References}

[1] Rebouillat, S. (2013) A Science and Business Equation for Collaborative Corporate Innovation. Business Strategy, IP Strategy, R \& D Strategy: An All-in-One Business Model. A Review with a Bio-Technology and Green Chemistry Focus. International Journal of Innovation and Applied Studies, 4, 1-19.

[2] Rebouillat, S. and Lapray, D. (2014) A Review Assessing the "Used in the Art” Intellectual Property Search Methods and the Innovation Impact Therewith. International Journal of Innovation and Applied Studies, 5, 160-191.

[3] Rebouillat, S. and Lapray, M. (2014) Bio-Inspired and Bio-Inspiration: A Disruptive Innovation Opportunity or a Matter of "Semantic"? A Review of a "Stronger than Logic" Creative Path Based on Curiosity and Confidence (4C22C(C). International Journal of Innovation and Applied Studies, 6, 299-325.

[4] Lapray, D. and Rebouillat, S. (2014) “Bigger Data” Visualization to Visual Analytics: A Path to Innovation. "Happening, Definitely! Misleading, Possibly?” A Review of Some Examples Applicable to IP Discovery. International Journal of Innovation and Applied Studies, 7, 1251-1273.

[5] Lapray, M. and Rebouillat, S. (2014) Innovation Review: Closed, Open, Collaborative, Disruptive, Inclusive, Nested... and Soon Reverse. How about the Metrics: Dream and Reality. International Journal of Innovation and Applied Studies, 9, 1-28.

[6] Rebouillat, S. and Pla, F. (2013) State of the Art Manufacturing and Engineering of Nanocellulose: A Review of Available Data and Industrial Applications. Journal of Biomaterials and Nanobiotechnology, 4, 165-188. http://dx.doi.org/10.4236/jbnb.2013.42022

[7] Björk, B.-C. and Solomon, D. (2013) The Publishing Delay in Scholarly Peer-Reviewed Journals. Journal of Informetrics, 7, 914-923. http://dx.doi.org/10.1016/j.joi.2013.09.001

[8] Miller, G.D., Jarvis, J.K. and McBean, L.D. (2006) The Importance of Milk and Milk Products in the Diet. Handbook of Dairy Foods and Nutrition. Third Edition, CRC Press, Boca Raton, 1-53. http://dx.doi.org/10.1201/9781420004311.ch1

[9] Jensen, R.G., Ferris, A.M. and Lammi-Keefe, C.J. (1991) The Composition of Milk Fat. Journal of Dairy Science, 74, 3228-3243. http://dx.doi.org/10.3168/jds.S0022-0302(91)78509-3

[10] Smith, K.E. (2001) Background on Milk Protein Products. Wisconsin Center for Dairy Research.

[11] Pouliot, Y. (2008) Membrane Processes in Dairy Technology_From a Simple Idea to Worldwide Panacea. International Dairy Journal, 18, 735-740. http://dx.doi.org/10.1016/j.idairyj.2008.03.005

[12] Saboya, L.V. and Maubois, J.L. (2000) Current Developments of Microfiltration Technology in the Dairy Industry. Lait, 80, 541-553. http://dx.doi.org/10.1051/lait:2000144

[13] Lawrence, N.D., Kentish, S.E., O'Connor, A.J., Barber, A.R. and Stevens, G.W. (2008) Microfiltration of Skim Milk Using Polymeric Membranes for Casein Concentrate Manufacture. Separation and Purification Technology, 60, 237244. http://dx.doi.org/10.1016/j.seppur.2007.08.016

[14] Hurt, E., Zulewska, J., Newbold, M. and Barbano, D.M. (2010) Micellar Casein Concentrate Production with a 3X, 3-Stage, Uniform Transmembrane Pressure Ceramic Membrane Process at 50 Degrees C. Journal of Dairy Science, 93, 5588-5600. http://dx.doi.org/10.3168/jds.2010-3169

[15] Hurt, E. and Barbano, D.M. (2010) Processing Factors that Influence Casein and Serum Protein Separation by Microfiltration. Journal of Dairy Science, 93, 4928-4941. http://dx.doi.org/10.3168/jds.2010-3121

[16] Goudedranche, H.Y.M., Maubois, J.J. and Fauquant, J.E. (1999) Products, in Particular, Milk Products, Comprising Selected Fractions of Fat Globules, Method for Obtaining Same and Use. Institut National de la Recherche Agronomique, WO/1999/048376.

[17] Goudedranche, H., Fauquant, J. and Maubois, J.L. (2000) Fractionation of Globular Milk Fat by Membrane Microfiltration. Le Lait, 80, 93-98. http://dx.doi.org/10.1051/lait:2000110

[18] Karasu, K., Glennon, N., Lawrence, N.D., Stevens, G.W., O’Connor, A.J., Barber, A.R., et al. (2010) A Comparison between Ceramic and Polymeric Membrane Systems for Casein Concentrate Manufacture. International Journal of Dairy Technology, 63, 284-289. http://dx.doi.org/10.1111/j.1471-0307.2010.00582.x

[19] Brans, G., Schroën, C.G.P.H., van der Sman, R.G.M. and Boom, R.M. (2004) Membrane Fractionation of Milk: State of the Art and Challenges. Journal of Membrane Science, 243, 263-272. http://dx.doi.org/10.1016/j.memsci.2004.06.029

[20] Skrzypek, M. and Burger, M. (2010) Isoflux ${ }^{\circledR}$ Ceramic Membranes-Practical Experiences in Dairy Industry. Desalination, 250, 1095-1100. http://dx.doi.org/10.1016/j.desal.2009.09.116 
[21] Yver, A.L., Bonnaillie, L.M., Yee, W., McAloon, A. and Tomasula, P.M. (2012) Fractionation of Whey Protein Isolate with Supercritical Carbon Dioxide-Process Modeling and Cost Estimation. International Journal of Molecular Sciences, 13, 240-259. http://dx.doi.org/10.3390/ijms13010240

[22] Bonnaillie, L., Qi, P., Wickham, E. and Tomasula, P. (2014) Enrichment and Purification of Casein Glycomacropeptide from Whey Protein Isolate Using Supercritical Carbon Dioxide Processing and Membrane Ultrafiltration. Foods, 3, 94-109. http://dx.doi.org/10.3390/foods3010094

[23] Bendixen, N., Hansen, S. and Lindau, J. (2008) Method in the Protein Fractionation of Skim Milk by Means of Microfiltration. Tetra Laval Holdings \& Finance SA, US Patent No. 20080171119.

[24] O’Mahony, J.A., Smith, K.E. and Lucey, J.A. (2007) Purification of Beta-Casein from Milk. Wisconsin Alumni Research Foundation, WO/2007/055932.

[25] Yan, L., Xiaohui, L., Fangxu, W. and Liebing, Z. (2010) Method for Separating Alpha S-Casein. China Agricultural University, CN Patent No. 101824085.

[26] Etzel, M.R., Arunkumar, A. and Agarwal, S. (2014) Methods and Compositions for Protein Concentration. WO/2014/ 127339.

[27] Shimatani, M. (2010) Composition Richly Containing Polar Lipid and Method of Manufacturing the Same. Molkerei Meggle Wasserburg GMBH \& Co., WO/2010/026229.

[28] Dickinson, E. (1997) Properties of Emulsions Stabilized with Milk Proteins: Overview of Some Recent Developments. Journal of Dairy Science, 80, 2607-2619. http://dx.doi.org/10.3168/jds.S0022-0302(97)76218-0

[29] Dickinson, E. (1998) Proteins at Interfaces and in Emulsions Stability, Rheology and Interactions. Journal of the Chemical Society-Faraday Transactions, 94, 1657-1669. http://dx.doi.org/10.1039/a801167b

[30] Dickinson, E. (1999) Adsorbed Protein Layers at Fluid Interfaces: Interactions, Structure and Surface Rheology. Colloids and Surfaces B: Biointerfaces, 15, 161-176. http://dx.doi.org/10.1016/S0927-7765(99)00042-9

[31] Dickinson, E. (2001) Milk Protein Interfacial Layers and the Relationship to Emulsion Stability and Rheology. Colloids and Surfaces B: Biointerfaces, 20, 197-210. http://dx.doi.org/10.1016/S0927-7765(00)00204-6

[32] Walstra, P. (1999) Casein Sub-Micelles: Do They Exist? International Dairy Journal, 9, 189-192. http://dx.doi.org/10.1016/S0958-6946(99)00059-X

[33] Phadungath, C. (2005) Casein Micelle Structure: A Concise Review. Songklanakarin Journal of Science and Technology, 27, 201-212.

[34] Uscn Life Science Inc. http://www.uscnk.com

[35] Fox, P.F. and Brodkorb, A. (2008) The Casein Micelle: Historical Aspects, Current Concepts and Significance. International Dairy Journal, 18, 677-684. http://dx.doi.org/10.1016/j.idairyj.2008.03.002

[36] Fox, P.F. (2001) Milk Proteins as Food Ingredients. International Journal of Dairy Technology, 54, 41-55. http://dx.doi.org/10.1046/j.1471-0307.2001.00014.x

[37] Roman, J.A. and Sgarbieri, V.C. (2006) The Hydrophilic, Foaming and Emulsifying Properties of Casein Concentrates Produced by Various Methods. International Journal of Food Science and Technology, 41, 609-617. http://dx.doi.org/10.1111/j.1365-2621.2005.01090.x

[38] WHO and FAO (2011) Codex Alimentarius: Milk and Milk Products. Second Edition, Food and Agriculture Organization of the United Nations and World Health Organization, Rome.

[39] Jovanović, S., Barać, M. and Maćej, O. (2005) Whey Proteins-Properties and Possibility of Application. Mljekarstvo, 55, 215-233.

[40] Foegeding, E.A., Luck, P. and Vardhanabhuti, B. (2011) Milk Protein Products/Whey Protein Products. Encyclopedia of Dairy Sciences. Academic Press, San Diego.

[41] Mehravar, R, Jahanshahi, M. and Saghatoleslami, N. (2009) Production of Biological Nanoparticles from Alpha-Lactalbumin for Drug Delivery and Food Science Application. African Journal of Biotechnology, 8, 6822-6827.

[42] Graveland-Bikker, J.F. and de Kruif, C.G. (2006) Unique Milk Protein Based Nanotubes: Food and Nanotechnology Meet. Trends in Food Science \& Technology, 17, 196-203. http://dx.doi.org/10.1016/j.tifs.2005.12.009

[43] Wang, X. (2003) Application of Preparing Health Products of Anti-Anoxia Made from Concentrated Powder of NonDenatured Lactalbumin. CN Patent No. 1415312-A.

[44] Liu, Y., Sun, X.M. and Li, B.H. (2006) Separation of Alpha-Lactalbumin and Beta-Lactoglobulin by a Convenient Liquid-Solid Extraction System: Application to Milk Whey. Chemical Engineering \& Technology, 29, 1424-1428. http://dx.doi.org/10.1002/ceat.200600223

[45] Kim, D.A., Cornec, M. and Narsimhan, G. (2005) Effect of Thermal Treatment on Interfacial Properties of $\beta$-Lactoglobulin. Journal of Colloid and Interface Science, 285, 100-109. http://dx.doi.org/10.1016/j.jcis.2004.10.044 
[46] Nicolai, T., Britten, M. and Schmitt, C. (2011) $\beta$-Lactoglobulin and WPI Aggregates: Formation, Structure and Applications. Food Hydrocolloids, 25, 1945-1962. http://dx.doi.org/10.1016/j.foodhyd.2011.02.006

[47] Moro, A., Báez, G.D., Ballerini, G.A., Busti, P.A. and Delorenzi, N.J. (2013) Emulsifying and Foaming Properties of $\beta$-Lactoglobulin Modified by Heat Treatment. Food Research International, 51, 1-7. http://dx.doi.org/10.1016/j.foodres.2012.11.011

[48] Pâquet, D. (1989) Review: The Proteose-Peptone Fraction of Milk. Lait, 69, 1-21. http://dx.doi.org/10.1051/lait:198911

[49] Karamoko, G., Anihouvi, P. and Blecker, C. (2013) The Development of Knowledge Regarding the Characteristics of the Proteose Peptone Fraction of Milk: Techno-Functional and Biological Properties: A Review. Biotechnologie Agronomie Societe et Environnement, 17, 373-382.

[50] Innocente, N., Comparin, D. and Corradini, C. (2002) Proteose-Peptone Whey Fraction as Emulsifier in Ice-Cream Preparation. International Dairy Journal, 12, 69-74. http://dx.doi.org/10.1016/S0958-6946(01)00166-2

[51] Innocente, N., Corradini, C., Blecker, C. and Paquot, M. (1998) Emulsifying Properties of the Total Fraction and the Hydrophobic Fraction of Bovine Milk Proteose-Peptones. International Dairy Journal, 8, 981-985. http://dx.doi.org/10.1016/S0958-6946(99)00021-7

[52] Faure, M., Bovetto, L.J.R., Montavon, P. and Schmitt, C. (2009) Production of Extract Enriched in a Proteose Peptone Fraction, Comprises Adjusting the $\mathrm{pH}$ of Aqueous Native Protein Dispersion, Heating the Dispersion, Removing Solid Aggregates and Collecting Remaining Liquid Fraction. WO2009103716-A2.

[53] Hoffman, J.R. and Falvo, M.J. (2004) Protein-Which Is Best? Journal of Sports Science and Medicine, 3, 118-130.

[54] Panyam, D. and Kilara, A. (1996) Enhancing the Functionality of Food Proteins by Enzymatic Modification. Trends in Food Science \& Technology, 7, 120-125. http://dx.doi.org/10.1016/0924-2244(96)10012-1

[55] Banach, J.C., Lin, Z. and Lamsal, B.P. (2013) Enzymatic Modification of Milk Protein Concentrate and Characterization of Resulting Functional Properties. Lwt-Food Science and Technology, 54, 397-403. http://dx.doi.org/10.1016/j.lwt.2013.06.023

[56] Gaonkar, G., Koka, R., Chen, K. and Campbell, B. (2010) Emulsifying Functionality of Enzyme-Modified Milk Proteins in $\mathrm{O} / \mathrm{W}$ and Mayonnaise-Like Emulsions. African Journal of Food Science, 4, 16-25.

[57] Davis, J.P., Doucet, D. and Foegeding, E.A. (2005) Foaming and Interfacial Properties of Hydrolyzed $\beta$-Lactoglobulin. Journal of Colloid and Interface Science, 288, 412-422. http://dx.doi.org/10.1016/j.jcis.2005.03.002

[58] O’Regan, J. and Mulvihill, D.M. (2010) Sodium Caseinate-Maltodextrin Conjugate Hydrolysates: Preparation, Characterisation and Some Functional Properties. Food Chemistry, 123, 21-31. http://dx.doi.org/10.1016/j.foodchem.2010.03.115

[59] Kumar, H.R.H., Monteiro, P.V., Bhat, G.S. and Rao, H.G.R. (2001) Effects of Enzymatic Modification of Milk Proteins on Flavour and Textural Qualities of Set Yoghurt. Journal of the Science of Food and Agriculture, 81, 42-45. http://dx.doi.org/10.1002/1097-0010(20010101)81:1<42::AID-JSFA771>3.0.CO;2-Q

[60] Adjonu, R., Doran, G., Torley, P. and Agboola, S. (2014) Whey Protein Peptides as Components of Nanoemulsions: A Review of Emulsifying and Biological Functionalities. Journal of Food Engineering, 122, 15-27. http://dx.doi.org/10.1016/j.jfoodeng.2013.08.034

[61] Gauthier, S.F. and Pouliot, Y. (2003) Functional and Biological Properties of Peptides Obtained by Enzymatic Hydrolysis of Whey Proteins. Journal of Dairy Science, 86, E78-E87. http://dx.doi.org/10.3168/jds.s0022-0302(03)74041-7

[62] Ettelaie, R., Zengin, A. and Lee, H. (2014) Fragmented Proteins as Food Emulsion Stabilizers: A Theoretical Study. Biopolymers, 101, 945-958. http://dx.doi.org/10.1002/bip.22487

[63] Motoki, M. and Seguro, K. (1998) Transglutaminase and Its Use for Food Processing. Trends in Food Science \& Technology, 9, 204-210. http://dx.doi.org/10.1016/S0924-2244(98)00038-7

[64] Han, X.-Q. and Damodaran, S. (1996) Thermodynamic Compatibility of Substrate Proteins Affects Their Cross-Linking by Transglutaminase. Journal of Agricultural and Food Chemistry, 44, 1211-1217. http://dx.doi.org/10.1021/jf950569x

[65] Ikura, K., Goto, M., Yoshikawa, M., Sasaki, R. and Chiba, H. (1984) Use of Transglutaminase. Reversible Blocking of Amino Groups in Substrate Proteins for a High Yield of Specific Products. Agricultural and Biological Chemistry, 48, 2347-2354. http://dx.doi.org/10.1271/bbb1961.48.2347

[66] Ma, H., Forssell, P., Partanen, R., Buchert, J. and Boer, H. (2011) Improving Laccase Catalyzed Cross-Linking of Whey Protein Isolate and Their Application as Emulsifiers. Journal of Agricultural and Food Chemistry, 59, 14061414. http://dx.doi.org/10.1021/jf103591p

[67] Hinz, K., Huppertz, T., Kulozik, U. and Kelly, A.L. (2007) Influence of Enzymatic Cross-Linking on Milk Fat Glo- 
bules and Emulsifying Properties of Milk Proteins. International Dairy Journal, 17, 289-293.

http://dx.doi.org/10.1016/j.idairyj.2006.05.001

[68] O’Sullivan, M.M., Kelly, A.L. and Fox, P.F. (2002) Influence of Transglutaminase Treatment on Some PhysicoChemical Properties of Milk. The Journal of Dairy Research, 69, 433-442. http://dx.doi.org/10.1017/S0022029902005617

[69] Færgemand, M., Otte, J. and Qvist, K.B. (1998) Emulsifying Properties of Milk Proteins Cross-Linked with Microbial Transglutaminase. International Dairy Journal, 8, 715-723. http://dx.doi.org/10.1016/S0958-6946(98)00111-3

[70] Sharma, R., Zakora, M. and Qvist, K.B. (2002) Characteristics of Oil-Water Emulsions Stabilised by an Industrial $\alpha$ Lactalbumin Concentrate, Cross-Linked before and after Emulsification, by a Microbial Transglutaminase. Food Chemistry, 79, 493-500. http://dx.doi.org/10.1016/S0308-8146(02)00225-X

[71] Færgemand, M., Murray, B.S. and Dickinson, E. (1997) Cross-Linking of Milk Proteins with Transglutaminase at the Oil-Water Interface. Journal of Agricultural and Food Chemistry, 45, 2514-2519. http://dx.doi.org/10.1021/jf9609789

[72] Dickinson, E., Ritzoulis, C., Yamamoto, Y. and Logan, H. (1999) Ostwald Ripening of Protein-Stabilized Emulsions: Effect of Transglutaminase Cross-Linking. Colloids and Surfaces B: Biointerfaces, 12, 139-146. http://dx.doi.org/10.1016/S0927-7765(98)00070-8

[73] Wilcox, C.P. and Swaisgood, H.E. (2002) Modification of the Rheological Properties of Whey Protein Isolate through the Use of an Immobilized Microbial Transglutaminase. Journal of Agricultural and Food Chemistry, 50, 5546-5551. http://dx.doi.org/10.1021/jf0117154

[74] Wilcox, C.P., Clare, D.A., Valentine, V.W. and Swaisgood, H.E. (2002) Immobilization and Utilization of the Recombinant Fusion Proteins Trypsin-Streptavidin and Streptavidin-Transglutaminase for Modification of Whey Protein Isolate Functionality. Journal of Agricultural and Food Chemistry, 50, 3723-3730. http://dx.doi.org/10.1021/jf011603c

[75] Lorenzen, P.C., Mautner, A. and Schlimme, E. (1999) Effect of Enzymatic Cross-Linking of Milk Proteins on the Resulting Properties of Yoghurt Products. Kieler Milchwirtschaftliche Forschungsberichte, 51, 89-97.

[76] Kuraishi, C., Yamazaki, K. and Susa, Y. (2001) Transglutaminase: Its Utilization in the Food Industry. Food Reviews International, 17, 221-246. http://dx.doi.org/10.1081/FRI-100001258

[77] Lorenzen, P.C., Neve, H., Mautner, A. and Schlimme, E. (2002) Effect of Enzymatic Cross-Linking of Milk Proteins on Functional Properties of Set-Style Yoghurt. International Journal of Dairy Technology, 55, 152-157. http://dx.doi.org/10.1046/j.1471-0307.2002.00065.x

[78] Phelan, M., Aherne, A., FitzGerald, R.J. and O’Brien, N.M. (2009) Casein-Derived Bioactive Peptides: Biological Effects, Industrial Uses, Safety Aspects and Regulatory Status. International Dairy Journal, 19, 643-654. http://dx.doi.org/10.1016/j.idairyj.2009.06.001

[79] Kamau, S.M., Lu, R.-R., Chen, W., Liu, X.-M., Tian, F.-W., Shen, Y., et al. (2010) Functional Significance of Bio- active Peptides Derived from Milk Proteins. Food Reviews International, 26, 386-401. http://dx.doi.org/10.1080/87559129.2010.496025

[80] Udenigwe, C.C. and Aluko, R.E. (2012) Food Protein-Derived Bioactive Peptides: Production, Processing, and Potential Health Benefits. Journal of Food Science, 77, R11-R24. http://dx.doi.org/10.1111/j.1750-3841.2011.02455.X

[81] Nagpal, R., Behare, P., Rana, R., Kumar, A., Kumar, M., Arora, S., et al. (2011) Bioactive Peptides Derived from Milk Proteins and Their Health Beneficial Potentials: An Update. Food \& Function, 2, 18-27. http://dx.doi.org/10.1039/C0FO00016G

[82] Rutherfurd-Markwick, K.J. (2012) Food Proteins as a Source of Bioactive Peptides with Diverse Functions. British Journal of Nutrition, 108, S149-S157. http://dx.doi.org/10.1017/s000711451200253x

[83] Benkerroum, N. (2010) Antimicrobial Peptides Generated from Milk Proteins: A Survey and Prospects for Application in the Food Industry: A Review. International Journal of Dairy Technology, 63, 320-338. http://dx.doi.org/10.1111/j.1471-0307.2010.00584.x

[84] PepBank. Massachusetts General Hospital, Harvard University. http://pepbank.mgh.harvard.edu

[85] Darewicz, M., Iwaniak, A. and Minkiewicz, P. (2014) Biologically Active Peptides Derived from Milk Proteins. Medycyna Weterynaryjna-Veterinary Medicine-Science and Practice, 70, 348-352.

[86] Hernández-Ledesma, B., del Mar Contreras, M. and Recio, I. (2011) Antihypertensive Peptides: Production, Bioavailability and Incorporation into Foods. Advances in Colloid and Interface Science, 165, 23-35. http://dx.doi.org/10.1016/j.cis.2010.11.001

[87] Hwang, J.-S., Tsai, Y.-L. and Hsu, K.-C. (2010) The Feasibility of Antihypertensive Oligopeptides Encapsulated in Liposomes Prepared with Phytosterols- $\beta$-Sitosterol or Stigmasterol. Food Research International, 43, 133-139. http://dx.doi.org/10.1016/j.foodres.2009.09.007 
[88] Gilani, G.S., Xiao, C. and Lee, N. (2008) Need for Accurate and Standardized Determination of Amino Acids and Bioactive Peptides for Evaluating Protein Quality and Potential Health Effects of Foods and Dietary Supplements. Journal of AOAC International, 91, 894-900.

[89] Nitschke, M. and Costa, S.G.V.A.O. (2007) Biosurfactants in Food Industry. Trends in Food Science \& Technology, 18, 252-259. http://dx.doi.org/10.1016/j.tifs.2007.01.002

[90] Nitschke, M., Ferraz, C. and Pastore, G.M. (2004) Selection of Microorganisms for Biosurfactant Production Using Agroindustrial Wastes. Brazilian Journal of Microbiology, 35, 81-85. http://dx.doi.org/10.1590/S1517-83822004000100013

[91] Rodrigues, L., Moldes, A., Teixeira, J. and Oliveira, R. (2006) Kinetic Study of Fermentative Biosurfactant Production by Lactobacillus Strains. Biochemical Engineering Journal, 28, 109-116. http://dx.doi.org/10.1016/j.bej.2005.06.001

[92] Dubey, K. and Juwarkar, A. (2001) Distillery and Curd Whey Wastes as Viable Alternative Sources for Biosurfactant Production. World Journal of Microbiology and Biotechnology, 17, 61-69. http://dx.doi.org/10.1023/A:1016606509385

[93] Campos, J.M., Stamford, T.L.M. and Sarubbo, L.A. (2014) Production of a Bioemulsifier with Potential Application in the Food Industry. Applied Biochemistry and Biotechnology, 172, 3234-3252. http://dx.doi.org/10.1007/s12010-014-0761-1

[94] Shete, A.M., Wadhawa, G., Banat, I.M. and Chopade, B.A. (2006) Mapping of Patents on Bioemulsifier and Biosurfactant: A Review. Journal of Scientific \& Industrial Research, 65, 91-115.

[95] Dewettinck, K., Rombaut, R., Thienpont, N., Le, T.T., Messens, K. and Van Camp, J. (2008) Nutritional and Technological Aspects of Milk Fat Globule Membrane Material. International Dairy Journal, 18, 436-457. http://dx.doi.org/10.1016/j.idairyj.2007.10.014

[96] Le, T.T., van Camp, J., Pascual, P.A.L., Meesen, G., Thienpont, N., Messens, K., et al. (2011) Physical Properties and Microstructure of Yoghurt Enriched with Milk Fat Globule Membrane Material. International Dairy Journal, 21, 798805. http://dx.doi.org/10.1016/j.idairyj.2011.04.015

[97] Lopez, C. (2011) Milk Fat Globules Enveloped by Their Biological Membrane: Unique Colloidal Assemblies with a Specific Composition and Structure. Current Opinion in Colloid \& Interface Science, 16, 391-404. http://dx.doi.org/10.1016/j.cocis.2011.05.007

[98] Corredig, M. and Dalgleish, D.G. (1998) Characterization of the Interface of an Oil-in-Water Emulsion Stabilized by Milk Fat Globule Membrane Material. Journal of Dairy Research, 65, 465-477. http://dx.doi.org/10.1017/S0022029998002982

[99] Singh, H. (2006) The Milk Fat Globule Membrane-A Biophysical System for Food Applications. Current Opinion in Colloid \& Interface Science, 11, 154-163. http://dx.doi.org/10.1016/j.cocis.2005.11.002

[100] Phan, T.T.Q., Le, T.T., Van der Meeren, P. and Dewettinck, K. (2014) Comparison of Emulsifying Properties of Milk Fat Globule Membrane Materials Isolated from Different Dairy By-Products. Journal of Dairy Science, 97, 4799-4810. http://dx.doi.org/10.3168/jds.2014-8030

[101] Spitsberg, V.L. (2005) Invited Review: Bovine Milk Fat Globule Membrane as a Potential Nutraceutical. Journal of Dairy Science, 88, 2289-2294. http://dx.doi.org/10.3168/jds.S0022-0302(05)72906-4

[102] Riccio, P. (2004) The Proteins of the Milk Fat Globule Membrane in the Balance. Trends in Food Science \& Technology, 15, 458-461. http://dx.doi.org/10.1016/j.tifs.2003.12.005

[103] Gerdes, S. (2008) Dairy Solutions to Application Challenges. Prepared Foods, 177, 77.

[104] Burling, H. and Graverholt, G. (2008) Milk-A New Source for Bioactive Phospholipids for Use in Food Formulations. Lipid Technology, 20, 229-231. http://dx.doi.org/10.1002/lite.200800058

[105] Zhu, D. and Damodaran, S. (2013) Dairy Lecithin from Cheese Whey Fat Globule Membrane: Its Extraction, Composition, Oxidative Stability, and Emulsifying Properties. Journal of the American Oil Chemists' Society, 90, 217-224. http://dx.doi.org/10.1007/s11746-012-2152-5

[106] Vesper, H., Schmelz, E.-M., Nikolova-Karakashian, M.N., Dillehay, D.L., Lynch, D.V. and Merrill, A.H. (1999) Sphingolipids in Food and the Emerging Importance of Sphingolipids to Nutrition. The Journal of Nutrition, 129, 1239-1250.

[107] Lecithin \& Phospholipids Market by Source (Soy, Sunflower, Egg, and Others), by Application (Food, Nutrition \& Supplements, Cosmetics, Feed, Pharmaceuticals, and Others)—Global Trends \& Forecasts to 2019, 2014. www.marketsandmarkets.com

[108] Bourlieu, C., Bouhallab, S. and Lopez, C. (2009) Biocatalyzed Modifications of Milk Lipids: Applications and Potentialities. Trends in Food Science \& Technology, 20, 458-469. http://dx.doi.org/10.1016/j.tifs.2009.05.005 
[109] Joshi, A., Paratkar, S.G. and Thorat, B.N. (2006) Modification of Lecithin by Physical, Chemical and Enzymatic Methods. European Journal of Lipid Science and Technology, 108, 363-373. http://dx.doi.org/10.1002/ejlt.200600016

[110] Lilbæk, H.M., Broe, M.L., Høier, E., Fatum, T.M., Ipsen, R. and Sørensen, N.K. (2006) Improving the Yield of Mozzarella Cheese by Phospholipase Treatment of Milk. Journal of Dairy Science, 89, 4114-4125. http://dx.doi.org/10.3168/jds.S0022-0302(06)72457-2

[111] Havn, S.S., Ipsen, R., Nielsen, P.M. and Lilbaek, H.M. (2006) Improving the Foaming Properties and Heat Stability of Whey Protein Concentrates by Phospholipase Treatment. Milchwissenschaft-Milk Science International, 61, 188-191.

[112] Lilbaek, H.M., Fatum, T.M., Ipsen, R. and Sorensen, N.K. (2007) Modification of Milk and Whey Surface Properties by Enzymatic Hydrolysis of Milk Phospholipids. Journal of Agricultural and Food Chemistry, 55, 2970-2978. http://dx.doi.org/10.1021/jf062705b

[113] Audic, J.L., Chaufer, B. and Daufin, G. (2003) Non-Food Applications of Milk Components and Dairy Co-Products: A Review. Le Lait, 83, 417-438. http://dx.doi.org/10.1051/lait:2003027 